Aguiar, D., Costa, L., \& Silva, E. (2017). An Attempt to Explain Differences in Economic Growth: A Stochastic Frontier Approach. Bulletin of Economic Research, 69(4), E42-E65. doi:

10.1111/boer.12102

\title{
AN ATTEMPT TO EXPLAIN DIFFERENCES IN ECONOMIC GROWTH: A STOCHASTIC FRONTIER APPROACH
}

\author{
Diana Aguiar \\ Católica Porto Business School, Universidade Católica Portuguesa, Portugal \\ dianaaguiar6b7@hotmail.com \\ Leonardo Costa \\ Católica Porto Business School, Universidade Católica Portuguesa, Portugal \\ lcosta@porto.ucp.pt
}

Elvira Silva

Faculdade de Economia do Porto, Center for Economics and Finance at UP (CEF.UP), Portugal esilva@fep.up.pt

Correspondence: Elvira Silva, Associate Professor of Economics, Faculdade de Economia do Porto, Center for Economics and Finance at UP (CEF.UP), Rua Doutor Roberto Frias, 4200-464 Porto, Portugal. Tel: +351225571100, E-mail: esilva@fep.up.pt

Acknowledgements: We gratefully acknowledge the valuable comments on earlier versions of the paper of two anonymous referees and Ricardo Ribeiro, a colleague from the Department of Economics of Católica Porto Business School. 


\title{
AN ATTEMPT TO EXPLAIN DIFFERENCES IN ECONOMIC GROWTH: A STOCHASTIC FRONTIER APPROACH
}

\begin{abstract}
Total factor productivity (TFP), factor accumulation, and growth are analyzed for a panel of 40 countries in 2001-2011. TFP growth and technical inefficiency are estimated using a stochastic frontier model. Environmental variables are found to have an important role in explaining differences in inefficiency across countries. Over 2001-2011, the general improvement in technical efficiency of countries is almost outweighed by technological regress. Results indicate that differences in factor accumulation between OECD and emergent economies are more important than differences in TFP change to explain differences in economic growth. Results also indicate negative and significant random shocks for the OECD countries.
\end{abstract}

Keywords: Economic growth, total factor productivity, technical efficiency, environmental variables, stochastic frontier analysis.

JEL classification numbers: C51, O12, O47, O57 


\section{INTRODUCTION}

Jones and Romer (2010) select the large differences in income across countries as one of the new stylized facts of growth. ${ }^{1}$ Why are some countries far richer than others? In order to understand the enormous disparities in economic performance across countries, we should investigate first the determinants of economic growth, that is, factors that explain the increase in a country's income per capita over a long period of time.

Determining the sources of discrepancies in the levels of production, and consequently in the standards of living, across countries, is a demanding and complex challenge that several studies have tried to address. The lively debate that one has witnessed is based on the relative importance of factor accumulation or productivity contribution to differences in economic performance. Simply put, output $=f$ (factors, productivity), where factors include physical and human capital, and economists do not seem to agree on which variable (factors or productivity) contributes more to differences in income levels and growth rates. According to Klenow and Rodriguez-Clare (1997), this debate is of great importance because the implications of each view (the factors or the productivity view) can differ substantially.

The purposes of this paper are threefold. First, differences in technical inefficiency are estimated and explained. Second, TFP change is estimated and decomposed into various components in order to evaluate the relative contribution of each component to productivity growth. Third, the relative importance of TFP growth and factor accumulation to economic growth is also evaluated. The sample is a balanced panel consisting of 34 OECD countries plus 6 emergent economies (Brazil, China, India, Indonesia, Russian Federation and South Africa) for the time period 2001-2011.

The paper proceeds as follows. Section 2 presents a brief literature review. Section 3 describes the data, the stochastic frontier model used in the empirical analysis as well as the decomposition of TFP growth. The empirical results are discussed in section 4 and concluding remarks are presented in section 5.

\section{LITERATURE REVIEW}

One of the most famous attempts to explain the determinants of economic growth is presented by Solow $(1956,1957)$, which established the roots of the neoclassic theory of

\footnotetext{
${ }^{1}$ According to the World Bank's World Development Indicators, in 2011, USA's output per worker (converted to 1990 constant international dollars using PPP rates) was approximately 7.5 times higher than output per worker in India.
} 
economic growth. In his 1956's seminal article, Solow proposes his neoclassical model, which can be seen as an extension of the Harrod-Domar model. He argues that, in order to sustain long-term economic growth, there must be continuous advances in technology in order to outweigh the effects of diminishing returns that would in due course cause economic growth to cease. Solow (1957) establishes the accounting framework for explaining income growth and the empirical results indicate that the growth rate of TFP, measured as a residual term (the Solow residual), has a predominant role in determining the growth rate of GDP per capita. Following the same line of thought, Kuznets (1971) concludes that the high rate of productivity growth accounts for most of the growth of output per capita. Even if hidden costs and inputs are considered, growth in productivity accounts for more than half of the growth in output per capita (Kuznets, 1971). Consequently, if the rate of change of productivity exerts such enormous influence on the growth rate of GDP per capita, as advocated by these two authors, it can be concluded, according to the Solow's model, that most of the economic growth is exogenously determined. Therefore, reliance on the exogenous technological progress as an essential variable to explain economic growth poses one of the biggest limitations of the neoclassical approach. This point of view was first expressed by Moses Abramovitz, who dubbed this term "a measure of our ignorance about the causes of economic growth" (Abramovitz, 1956).

Latter attempts to scrutinize the content of the Solow residual gave rise to a new set of theories named "endogenous growth theories”. By endogenizing a country's technology, these theories advocate that factor accumulation is not sufficient to explain differences in income growth and try to explain the differences in the growth of the residual by analyzing the choices of the public and private sector. ${ }^{2}$ As an example, in Romer's (1990) model, growth is motivated by technological change that emerges from deliberate investment decisions made by profit-maximizing agents. According to its defenders, these theories provide policymakers with more relevant information regarding the determinants of long-run economic growth than the standard neoclassical framework.

However, in the recent past there has been a plethora of empirical studies that contradict the idea that physical and human capital accumulation is not sufficient to

\footnotetext{
${ }^{2}$ The neoclassical framework postulates that a common (exogenously determined) technology is shared by every country due to the non-rivalry and non-exclusivity nature of the technological progress (note that the growth of the residual, that is the growth of productivity, essentially mirrors this technological progress). Consequently, technological progress cannot explain differences in GDP per capita across countries and one has to look for differences in factor accumulation.
} 
explain differences in levels and growth rates of output per capita. Mankiw et al. (1992) conclude that the augmented Solow model (an extension of the original neoclassical Solow model that includes human as well as physical capital) provides a very good picture of the cross-country data. They predicted that the augmented Solow model accounts about $80 \%$ for the cross-country variance in income in 1985. Young (1995) documents the fundamental role played by factor accumulation (rather than the rise in productivity) in explaining the astonishing post-war growth of the East Asian countries. Klenow and Rodriguez-Clare (1997) call these set of studies the "neoclassical revival", mainly because they advocate that differences in physical and human capital are the main contributors to the differences in the level and growth rate of GDP.

According to Klenow and Rodriguez-Clare (1997), this debate is of great importance because the implications of each view (the factors or the productivity view) can differ substantially. For instance, technology-based models of productivity, by assuming scale effects due to the non-rival nature of technology creation and adoption, indicate that international trade openness can have direct effects on per capita income levels and growth rates. The neoclassical approach does not share this view, and assumes that the production frontier is common across countries. More recently, this crucial assumption is again questioned by several empirical studies - Knight et al. (1993), Islam (1995) and Caselli et al. (1996), to name a few - which show that the income-convergence predicted by the neoclassical framework is occurring but conditioned on the existence of differences in the production frontier across countries. In fact, by analyzing recent contributions to the economic growth literature, one can observe an increasing focus on TFP growth as the main driver of long-term income growth and cross-country differences in per capita income. Klenow and Rodriguez-Clare (1997) uses the Mincer-regression to estimate the levels and growth rates of human capital and find out that differences in the level and growth rate of the TFP play a fundamental role in explaining the differences in income levels and growth rates. Hall and Jones (1999) focus on levels instead of growth rates and calculate the TFP level as the Solow residual. Differences in physical and human capital can only partially explain differences in GDP per worker and most of the variance in income per capita is due to a large fluctuation in the level of the Solow residual across countries (Hall and Jones, 1999). Easterly and Levine (2001) identify TFP as the main contributor to the cross-country differences in the level and growth rate of per capita income and named it a stylized factor. In 2013, the Organization for Economic Co- 
operation and Development (OECD) identified productivity growth as the key factor to improve per capita income and hence standards of living.

The results in recent economic growth literature, by favoring the importance of productivity over factor accumulation in explaining the differences in income levels and growth, reinforce the need of a better understanding of TFP and its determinants in order to design policies most conducive to TFP growth, and therefore, long-run economic growth. Consequently, several authors have tried to address this issue. These studies emphasize the importance of institutions and government policies (e.g., Hall and Jones, 1999; Acemoglu et al., 2004; Afonso and St. Aubyn, 2013; Christie, 2014; Hu et al., 2014; Bayraktar and Moreno-Dodson, 2015), human capital (e.g., Barro, 2001; Aiyar and Feyrer, 2002; Afonso and St. Aubyn, 2013), trade openness (e.g., Edwards, 1998; Baldwin and Gu, 2004; Dollar and Kraay, 2004), and the role of natural resources (e.g., Delíktas and Bacilar, 2005), in boosting productivity growth.

\section{DATA AND EMPIRICAL MODEL}

This section describes the data and discusses the specification of the stochastic production frontier model as well as the decomposition of TFP change.

\section{III.1 Description of the Sample}

The sample includes 34 OECD countries plus 6 emergent economies in the time period 20012011. In spite of evident differences between OECD countries and emergent economies, both set of economies play an extremely important role in the global economy. ${ }^{3}$ In fact, these countries as a whole account for approximately $90 \%$ of the world GDP and $64 \%$ of the world's population (Table 1). The rationale underlying the choice of the countries is the following: the sample must include countries with size or strategic importance that make them crucial players in the global market (Table 2).

Note that our sample does not include poor countries. According to Pires and Garcia (2012), the exclusion of poor countries does not lead to a selection bias, if the parametric functional form specification of the production frontier is flexible by allowing the output elasticity with respect to each input to vary across countries and over time. The empirical model, presented below, specifies a translog stochastic production frontier.

\footnotetext{
${ }^{3}$ By "Emergent economies" we are referring to the economies of Brazil, China, India, Indonesia, Russian Federation and South Africa.
} 
TABLE 1

GDP per capita and GDP per worker in 2011

\begin{tabular}{lcccccc}
\hline \multicolumn{1}{c}{ Country } & Population & & & & GDP per \\
(millions) & $(\%)$ & $\begin{array}{c}\text { GDP constant } \\
\text { 2005 US\$ } \\
\text { (millions) }\end{array}$ & $\begin{array}{c}\text { GDP per } \\
\text { worker } \\
\text { capita } \\
\text { (constant } \\
\text { 2005 US\$) }\end{array}$ & $\begin{array}{c}\text { (constant } \\
1990 \text { PPP } \\
\$ \text { ) }\end{array}$ \\
\hline World & $6.964,64$ & 100 & $54.024 .630,72$ & 100 & $7.756,99$ & $18.551,59$ \\
OECD members & $1.248,58$ & 17,93 & $39.502 .455,53$ & 73,12 & $31.637,91$ & $47.649,46$ \\
Emergent economies & $3.200,56$ & 45,95 & $8.299 .961,87$ & 15,36 & $24.032,35$ & 80.887 \\
Brazil & 196,94 & 2,83 & $1.126 .722,92$ & 2,09 & $5.721,29$ & 13.592 \\
China & $1.344,13$ & 19,30 & $4.196 .333,19$ & 7,77 & $3.121,97$ & 14.203 \\
India & $1.221,16$ & 17,53 & $1.326 .235,11$ & 2,45 & $1.086,05$ & 8.875 \\
Indonesia & 243,8 & 3,50 & $402.408,02$ & 0,74 & $1.650,56$ & 11.002 \\
Russian Federation & 142,96 & 2,05 & $948.019,77$ & 1,75 & $6.631,53$ & 19.012 \\
South Africa & 51,58 & 0,74 & $300.242,87$ & 0,56 & $5.820,96$ & 14.203 \\
\hline
\end{tabular}

Source: World Bank (2015)

TABLE 2

GDP per capita growth and GDP growth in 2011

\begin{tabular}{lcrc}
\hline \multicolumn{1}{c}{ Country } & $\begin{array}{c}\text { Population growth } \\
\text { (annual \%) }\end{array}$ & $\begin{array}{c}\text { GDP per capita } \\
\text { growth } \\
\text { (annual \%) }\end{array}$ & $\begin{array}{c}\text { GDP growth } \\
\text { (annual \%) }\end{array}$ \\
\hline World & 1,18 & 1,59 & 2,79 \\
OECD members & 0,67 & 1,04 & 1,71 \\
Emergent economies & 0,88 & 3,72 & 7,00 \\
Brazil & 0,88 & 1,83 & 2,73 \\
China & 0,48 & 8,78 & 9,30 \\
India & 1,28 & 5,28 & 6,64 \\
Indonesia & 1,29 & 5,12 & 6,49 \\
Russia Federation & 0,40 & 3,85 & 4,26 \\
South Africa & 1,33 & 2,23 & 3,60 \\
\hline
\end{tabular}

Source: World Bank (2015)

The time period considered in the analysis is 2001-2011, mainly for two reasons. First, the impacts of the last decade of globalization and the global financial crisis are investigated by specifying it as an environmental variable in the technical inefficiency model. Second, the euro was introduced in January 1999 in eleven countries and the physical euro coins and notes replaced the old national currencies in the eurozone in 2002. Inclusion of years previous to 2001 would reflect structural changes different from the ones we aim to analyze. 2011 is the last year for which the desired data was available. 
TABLE 3

Data summary for 40 countries over the period 2001-2011

\begin{tabular}{lcccc}
\hline Variable & Mean & Std. Dev. & Minimum & Maximum \\
\hline Real GDP per worker $(y)$ & 5.33 & 2.36 & 0.50 & 11.67 \\
Index of human capital per worker $(h)$ & 2.96 & 0.39 & 1.76 & 3.62 \\
Capital stock per worker $(k)$ & 17.22 & 8.75 & 0.91 & 38.03 \\
& & & & \\
Environmental variables $(z):$ & & & & \\
Agriculture & 3.95 & 3.79 & 0.30 & 22.92 \\
Natresources & 3.45 & 6.01 & 0.00 & 38.41 \\
Tariffs & 2.76 & 2.58 & 0.00 & 26.50 \\
Lifexpect & 76.82 & 5.65 & 51.56 & 85.16 \\
Timeinsolv & 2.15 & 1.44 & 0.40 & 10.00 \\
Patents & 24.46 & 69.49 & 0.00 & 415.83 \\
Regulatory & 1.10 & 0.62 & -0.78 & 1.97 \\
Urban & 73.17 & 14.59 & 27.98 & 97.49 \\
Govdebt & 52.63 & 28.18 & 3.61 & 189.83 \\
\hline
\end{tabular}

Source: World Bank (2013)

Table 3 provides summary statistics of the variables used in the estimation of the stochastic production frontier with time-varying inefficiency. The variables considered are the following: the real GDP per worker $(y)$ at current PPPs (in 10 thousands 2005US\$); the index of human capital per worker $(h)$; the capital stock per worker $(k)$ at current PPPs (in 10 thousands 2005US\$); and a vector $(z)$ of environmental variables to explain cross-country differences in inefficiency. The index of human capital per worker $(h)$ is constructed using data on the average years of schooling for the working-age population from Barro and Lee (2013) and rates of return associated with different years of education (Psacharopoulos, 1994). The capital stock per worker $(k)$ is obtained by dividing the capital stock at current PPPs by the number of workers. The components of vector $\mathrm{z}$ and their definition are as follows:

- $\quad$ agriculture is the value added of agriculture measured as a percentage of GDP;

- $\quad$ natresources is the total rents from natural resources as a percentage of GDP;

- $\quad$ tariffsis the weighted average of tariff rates of all products (\%);

- lifexpect is the number of years of life expectancy at birth;

- $\quad$ timeinsolv is the number of years necessary to resolve an insolvency; 
- regulatoryis a composite index reflecting regulatory quality, assuming values between -2.5 and 2.5, where higher values correspond to better outcomes;

- $\quad$ patents is the resident patent applications measured in thousands of units;

- urban is the urban population as a percentage of the total population;

- $\quad$ govdebt is the total central government debt as a percentage of GDP;

- $\quad d E U$ crisis is a dummy variable that assumes the value 1 for the 27-EU countries for the years 2009 to 2011 and 0 otherwise.

The environmental variables, which were collected from the World Development Indicators database from World Bank, attempt to reflect countries' specific characteristics that may influence technical inefficiency and productivity change, and that can help to design policies most conducive to TFP growth. Several studies have tried to address this issue. These studies emphasize the importance of institutions and government policies (e.g., Hall and Jones, 1999; Acemoglu et al., 2004; Afonso and St. Aubyn, 2013), human capital (e.g., Barro, 2001; Aiyar and Feyrer, 2002; Afonso and St. Aubyn, 2013), trade openness (e.g., Edwards, 1998; Baldwin and Gu, 2003; Dollar and Kraay, 2004), the roles of natural resources (e.g., Deliktas and Bacilar, 2005), among others, in boosting productivity growth. The environmental variables considered in this study are: economic structure, trade, demography, institutions, innovation, urbanization, government finance and the global financial crisis.

The economic structure of a country is captured by the value added of the agriculture sector and the total rents from natural resources as a percentage of GDP. Both variables are good proxies of the weight of the primary sector in an economy and the contribution of total natural resources rents to GDP is an important basis for the analysis of the sustainability of economic growth. Trade is represented by the weighted average of tariff rates, considering that not all countries set equal tariffs to all products, and may set high tariffs to protect favored domestic sectors. Life expectancy at birth is an important demographic variable indicating the health status of a country and, according to the World Bank, it is one of the most frequently used indicators to compare socioeconomic development across countries.

Institutions can be defined as the rules and organizations that set the production environment (Doucouliagos and Ulubaşoğlu, 2008). The quality of a country's institutions is captured by the variables time to resolve insolvency, which mirrors the 
quality of the business environment, and regulatory quality, which reflects the governance of a country. The selection of both variables required the construction of two correlation matrices. The first matrix included all variables in the World Bank Doing Business Index as well as the real GDP per worker, while the second matrix included all variables of the Worldwide Governance Indicators plus the output variable. Each of the correlation matrix indicates that it is better to include only one variable reflecting business environment and one reflecting the governance of a country in order to avoid multicollinearity problems and the variables time to resolve insolvency and regulatory quality were appropriate choices given the strong correlation with GDP per worker.

Innovation is represented by the resident patent applications. A correlation matrix of all indicators of the Global Innovation Index and the real GDP per worker was constructed and the analysis resulted in the selection of this variable.

Urban population, measured as a percentage of the total population reflects the degree of development of a country. In principle, cities generate jobs and income, and deliver education, health care and other services more efficiently than rural areas. The government finance is represented by the central government debt measured as a percentage of the GDP. High levels of public debt are likely to have a negative impact on economic growth, although this effect may be relevant only after a certain threshold.

The effects of the global crisis on the economic performance of countries are represented by a dummy variable that assumes the value 1 for the $27-\mathrm{EU}$ countries for the time period 2009-2011 and 0 otherwise. This variable attempts to differentiate the impact that the crisis had on the 27-EU countries in comparison with other regions, given that those effects were seriously aggravated after the financial crisis turned into a sovereign debt crisis in 2009 , leading to high constraints on public finances and fiscal sustainability in several EU countries.

\section{III.2 A Stochastic Frontier Time-Varying Inefficiency Model}

This study uses the Battese and Coelli (1995) stochastic production frontier model for (balanced/unbalanced) panel data assuming a translog functional form. For an overview 
of stochastic frontier models, see Kumbhakar and Lovell (2000) and Kumbhakar et al. (2015).

The stochastic production frontier model is specified as follows: ${ }^{4}$

$$
\begin{aligned}
\ln \left(y_{i t}\right)= & \beta_{0}+\beta_{h} \ln \left(h_{i t}\right)+\beta_{k} \ln \left(k_{i t}\right)+\beta_{t} t+\beta_{h k} \ln \left(h_{i t}\right) \ln \left(k_{i t}\right) \\
& +\frac{1}{2}\left[\beta_{h h}\left(\ln \left(h_{i t}\right)\right)^{2}+\beta_{k k}\left(\ln \left(k_{i t}\right)\right)^{2}+\beta_{t t} t^{2}\right]+v_{i t}-u_{i t}
\end{aligned}
$$

and technical inefficiency is modeled as a function of environmental variables:

$$
u_{i t}=z_{i t} \delta+w_{i t}
$$

where $t$ is the year of observation, $v_{i t} \sim$ iid $N\left(0, \sigma_{v}^{2}\right), u_{i t}$ is the non-negative random technical inefficiency component of the error term, $u_{i t} \sim$ iid $N^{+}\left(z_{i t} \delta, \sigma_{u}^{2}\right)$ truncated at zero, and $w_{i t}$ is a random variable defined by the truncation of the normal distribution with zero mean and variance $\sigma_{w}^{2}$. The time index $t$ is also a component of the $z$ vector.

Time- and country-specific technical inefficiency is estimated as follows:

$$
T E_{i t}=\exp \left(-\hat{u}_{i t}\right)
$$

The empirical model specified in (1) and (2) is estimated using the Maximum Likelihood method. The likelihood function and its partial derivatives with respect to the parameters of the model are presented in Battese and Coelli (1992).

Several alternative specifications of the model in (1) and (2) were tested using the likelihood ratio test statistics. All tests favored the adoption of a translog production frontier with Hicks-neutral technological change and inefficiency effects, $u_{i t}$, specified as a linear function of the environmental variables. The results of these testes are presented in Appendix A. Variable $t$ is present in both equations (1) and (2) in order to include both technical change and time-varying inefficiency effects. Similarly to the original Battese and Coelli (1995) model, the $t$ variable in equation (1) accounts for Hicks-neutral

\footnotetext{
${ }^{4}$ Globalization, in recent decades, has led to free capital mobility (FDI and portfolio investment) and a worldwide increase in human capital as well as to integrated production processes across countries and/or Global Value Chains (see for instance WTO Made in the World). These facts may be particularly relevant for OECD countries and emerging economies, which became more connected than ever in recent decades, and support the choice of a common production frontier. In other words, no technological gap between the OECD and emergent countries in the sample is assumed in this study.
} 
technical change, while the $t$ variable in equation (2) specifies that the inefficiency effects may change, ceteris paribus, linearly with time. The presence of this variable in both equations and the distributional assumptions on the inefficiency effects allow disentangling the effects of technical change and inefficiency change.

Given the empirical model specified in (1) and (2), TFP change is decomposed into three components, as follows (e.g., Kumbhakar and Lovell (2000)):

$$
T F P \Delta=T \Delta+T E \Delta+S \Delta
$$

where

$$
\begin{aligned}
& T \Delta=\beta_{t}+\beta_{t t} t \\
& T E \Delta=-\frac{\partial \mu}{\partial t}=-\delta \frac{\partial z}{\partial t}-\frac{\partial w}{\partial t} \\
& \varepsilon_{h}=\beta_{h}+\beta_{h h} \ln (h)+\beta_{h k} \ln (k) \\
& \varepsilon_{k}=\beta_{k}+\beta_{k k} \ln (k)+\beta_{h k} \ln (h) \\
& \varepsilon=\beta_{h} \beta_{k}+\left(\beta_{h h}+\beta_{h k}\right) \ln (h)+\left(\beta_{k k}+\beta_{h k}\right) \ln (k) \\
& S \Delta=(\varepsilon-1)\left[\left(\frac{\varepsilon_{h}}{\varepsilon}\right) \dot{h}+\left(\frac{\varepsilon_{k}}{\varepsilon}\right) \dot{k}\right]
\end{aligned}
$$

Equation (5) shows that technical change varies only over time due to Hicks-neutral technological change. $T \Delta>0$ indicates an upward shift in the production frontier (i.e., technological progress), $T \Delta<0$ represents a downward shift in the production frontier (i.e., technological regress) and $T \Delta=0$ means that the frontier remains unchanged. Technical efficiency change varies across countries and over time, as shown in equation (6), where $T E \Delta>0$ means that the country moves towards the production frontier (i.e., the country becomes more efficient), TE $<0$ represents a movement away of the frontier, and $T E \Delta=0$ means that the position of the country in relation to the production frontier remains unchanged. Output elasticity with respect to each input (equations (7) and (8)) and the scale elasticity (equation (9)) vary over time and across countries. Consequently, the scale economies component, $S \Delta$, varies over time and across countries. The impact of the scale component on productivity change depends on the type of technology and the aggregate input rate. Under constant returns to scale, the aggregated input growth rate has no effect on productivity change. The scale economies component has a positive effect on TFP change if $\varepsilon>1$ and the aggregated input growth rate is 
positive or in the case of input contraction and $\varepsilon<1$. Note that TFP change in equation (4) is expected to vary over time and across countries.

Moreover, the decomposition in (4) allows separating the explained components of economic growth from the random shocks. The random shocks component is obtained residually, by subtracting the sum of the growth rate of inputs per worker, weighted by the corresponding expenditure share, and the growth rate of TFP from the growth rate of GDP per worker.

\section{EMPIRICAL RESULTS}

\section{IV.1 Estimates of the stochastic production frontier}

The maximum likelihood estimates of the parameters of the model specified in (1)-(2) are presented in Table $4 .{ }^{5}$ All parameters are significant at $5 \%$. The elasticity of output per worker with respect to human capital per worker (physical capital per worker), evaluated at the sample mean, is $0.24(0.59)$. Therefore, the elasticity of scale, measured at the sample mean, is equal to 0.83 , which reflects decreasing returns to scale. Results on the Allen partial elasticity of substitution between human and physical capital per worker are presented in Appendix B. The elasticity of substitution between the two input factors, measured at the sample mean, is approximately 0.1, suggesting that both inputs are substitutes and strongly inelastic. Thus, these input factors have limited substitution possibilities.

The coefficient $\beta_{t}$ is negative and more than offsets the positive effect coming from the positive sign and magnitude of $\beta_{t t}$, contributing to a negative technical change every year. This indicates technological regress over the period 2001-2011, with an estimated annual rate of $-7.07 \%$.

\footnotetext{
${ }^{5}$ The Bartlett's test for equal variances was conducted for the technical efficiency scores as well as for the estimates of the symmetric error term. Results of the Bartlett's tests indicate that $u$ is not heteroscedastic, yet the hypothesis of $v$ being heteroscedastic cannot be rejected. Thus, the estimates of the frontier function parameters are consistent, except the intercept which is downward biased. As a tentative solution, we estimated model 2 in Kumbhakar et al. (2014), which allows to modelling the heteroscedasticity of $v$, by specifying the standard deviation of $v$ as a function of environmental variables. However, the available environmental variables are scarce and, after several attempts, the heteroscedasticity problem of $v$ remained (we checked it using the Bartlett's test). For this reason, we do not change the specification of the frontier model presented in section III.2. By doing so, the estimates of technical efficiency are, in fact, underestimated (due to the bias of the intercept). However, the technical inefficiency estimates are relatively unbiased, since the heteroscedasticity of $v$ affects only the constant term of the frontier function. In other words, the Battese and Coelli (1995)'s model allows us to establish an unbiased technical efficiency ranking among countries.
} 
TABLE 4

Estimates of the stochastic frontier time-varying inefficiency model

\begin{tabular}{|c|c|c|c|c|c|c|c|}
\hline \multicolumn{4}{|c|}{ Number of observations $=440$} & \multicolumn{4}{|c|}{ Observations per country: Minimum $=11$} \\
\hline Number of coun & tries $=$ & 40 & & & & \multicolumn{2}{|c|}{ Maximum $=11$} \\
\hline Number of year & $=11$ & & & & & \multicolumn{2}{|c|}{ Average $=11$} \\
\hline \multicolumn{4}{|c|}{ Log Likelihood = 217.0422} & \multicolumn{3}{|c|}{$\begin{array}{l}\text { Prob }>\chi^{2}=0.0000 \\
\text { Wald } \chi^{2}(7)=628.00\end{array}$} & \\
\hline \multirow{2}{*}{$\ln y$} & \multirow{2}{*}{\multicolumn{2}{|c|}{ Coefficients }} & \multirow{2}{*}{$\begin{array}{l}\text { Standard } \\
\text { Error }\end{array}$} & \multirow{2}{*}{$\mathrm{z}$} & \multirow{2}{*}{$\mathrm{P}>|z|$} & \multicolumn{2}{|c|}{$95 \%$ Confidence Interval } \\
\hline & & & & & & Lower & Upper \\
\hline \multicolumn{8}{|l|}{ Frontier } \\
\hline $\ln (h)$ & $\beta_{h}$ & -5.809128 & 1.147038 & -5.06 & 0.000 & -8.057282 & -3.560974 \\
\hline $\ln (k)$ & $\beta_{k}$ & 0.7064641 & 0.1479122 & 4.78 & 0.000 & 0.4165614 & 0.9963668 \\
\hline$t$ & $\beta_{t}$ & -0.0981486 & 0.0253975 & -3.86 & 0.000 & -0.1479267 & -0.0483704 \\
\hline$\frac{1}{2}(\ln (h))^{2}$ & $\beta_{h h}$ & 4.113806 & 1.469301 & 2.80 & 0.005 & 1.234029 & 6.993583 \\
\hline$\frac{1}{2}(\ln (k))^{2}$ & $\beta_{k k}$ & -0.2920147 & 0.0573869 & -5.09 & 0.000 & -0.4044909 & -0.1795384 \\
\hline$\frac{1}{2} t^{2}$ & $\beta_{t t}$ & 0.0045607 & 0.0020993 & 2.17 & 0.030 & 0.0004461 & 0.0006754 \\
\hline $\ln (h) * \ln (k)$ & $\beta_{h k}$ & .6141446 & 0.2106014 & 2.81 & 0.005 & 0.1856937 & 1.042595 \\
\hline Const. & $\beta_{0}$ & 3.753954 & 0.51971394 & 7.22 & 0.000 & 2.735283 & 4.772624 \\
\hline \multicolumn{8}{|l|}{$M$} \\
\hline Agriculture & $\delta_{1}$ & 0.0307487 & 0.0054211 & 5.67 & 0000 & 0.0201235 & 0.0413738 \\
\hline Nat Resources & $\delta_{2}$ & 0.0048014 & 0.0016155 & 2.97 & 0.003 & 0.0016351 & 0.0079677 \\
\hline Tariffs & $\delta_{3}$ & 0.014778 & 0.0035337 & 4.18 & 0.000 & 0.0078522 & 0.0217039 \\
\hline Life expect & $\delta_{4}$ & -0.0035429 & 0.0023082 & -1.53 & 0.125 & -0.0080669 & 0.000981 \\
\hline Time insolv & $\delta_{5}$ & 0.0497739 & 0.0065565 & 7.59 & 0.000 & 0.0369234 & 0.0626244 \\
\hline Regulatory & $\delta_{6}$ & -0.1080597 & 0.0233531 & -4.63 & 0.000 & -0.153831 & -0.0622885 \\
\hline Patents & $\delta_{7}$ & 0.0007503 & 0.000132 & 5.68 & 0.000 & 0.0004915 & 0.0010091 \\
\hline Urban & $\delta_{8}$ & -0.0008899 & 0.0008697 & -1.02 & 0.306 & -0.0025944 & 0.0008146 \\
\hline Gov debt & $\delta_{9}$ & 0.0008052 & 0.0003302 & 2.44 & 0.015 & 0.0001581 & 0.0014524 \\
\hline dEUcrisis & $\delta_{10}$ & 0.1145139 & 0.0360738 & 3.17 & 0.002 & 0.0438106 & 0.1852172 \\
\hline$t$ & $\delta_{11}$ & -0.0623471 & 0.0182371 & -3.42 & 0.001 & -0.0980911 & -0.026603 \\
\hline \multirow[t]{5}{*}{ Const. } & $\delta_{0}$ & 0.9465922 & 0.2487099 & 3.81 & 0.000 & 0.4591297 & 1.434055 \\
\hline & $\sigma_{u}$ & 0.1154147 & 0.0237713 & 4.98 & 0.000 & 0.0798969 & 0.1755017 \\
\hline & $\sigma_{v}$ & 0.0968468 & 0.026857 & 3.61 & 0.000 & 0.0562387 & 0.1667767 \\
\hline & & 1.222701 & 0.0499933 & 24.6 & 0.000 & 1.124716 & 1.320686 \\
\hline & & 0.586812 & & & & & \\
\hline
\end{tabular}


The estimated variance parameter $\gamma=\frac{\sigma_{u}^{2}}{\sigma^{2}}$, where $\sigma^{2}=\sigma_{u}^{2}+\sigma_{v}^{2}$, is approximately 0.6 , meaning that $60 \%$ of the total composed error variance is explained by the variance of $u$. This reflects the importance of incorporating technical inefficiency in the model.

The standard errors of $u$ and $v$ are statistically different from 0 , indicating that inefficiency effects are stochastic and the traditional production function does not fit the data well. ${ }^{6}$

\section{IV.2 Technical inefficiency estimates}

The set of country-specific variables considered in the technical inefficiency model, specified in (2), explains partially the differences in inefficiency (and productivity growth) across countries and over time. All parameters, except $\delta_{4}$ and $\delta_{8}$, are statistically significant at 5\% (Table 4).

The weight of agriculture in the economy has a positive effect in inefficiency $\left(\delta_{1}>\right.$ 0 ), suggesting that the higher the contribution of the agricultural sector to the economy as a whole, ceteris paribus, the higher is the inefficiency of a country. Ceteris paribus, countries with a lower weight of the primary sector are expected to be more efficient, and hence, more productive. The impact of agriculture in the productivity of a country is still a controversial topic in the literature. Some authors believe that agriculture is the reason for the huge difference between the productivity growth of central and peripheral countries. ${ }^{7}$ Prebisch (1984), for example, argues that peripheral countries have low productivity growth because they focus in supplying primary goods. Jaumotte and Spatafora (2007) find out that the transition of economic activity from agricultural to nonagricultural sectors has two types of sectorial effects: $(i)$ the sectorial reallocation effect which reflects an increase in aggregate TFP due to the reallocation of resources from a low-productivity to a high-productivity sector; and (ii) the sectorial composition effect which reflects the increase in TFP growth when a country's value added comes mainly from high-productivity growth sectors. Chanda and Dalgaard (2008) argued that 30 to $50 \%$ of cross-country variation in TFP is due to differences in the sectorial composition

\footnotetext{
${ }^{6}$ According to Battese and Coelli (1995), if $\sigma_{u}$ and $\sigma_{v}$ are not statistically different from zero, the model would reduce to a traditional mean response function with the $z$-variables belonging to the production function.

${ }^{7}$ By central and peripheral countries, Prebisch (1984) means industrialized countries and the primary producers, respectively.
} 
of GDP. In particular, the allocation of resources between non-agricultural and agricultural sectors affects productivity growth, with agricultural shares affecting negatively TFP. Other studies (e.g., Krueger et al., 1988; Restuccia et al., 2008) argue that the sources of low productivity in the agriculture sector are due to the low economywide productivity in those countries and the imposition of barriers to the use of modern intermediate inputs that could, otherwise, lead to an improvement of productivity in this sector. On the other hand, some other studies report much higher TFP growth rates for agriculture relative to other sectors, creating, therefore, the need to reevaluate the association of low levels of TFP growth to the modern agriculture (e.g., OECD, 1995; Bernard and Jones, 1996; Martin and Mitra, 2001). ${ }^{8}$

Resource abundance has a negative impact on the efficiency of a country $\left(\delta_{2}>0\right)$. This result is consistent with the evidence that shows that countries with high stocks of natural resources tend to be less productive and grow slower than resource-poor countries. Sachs and Warner (2001) named it a "curse of natural resources". Several reasons are pointed out to explain this result. In particular, Sachs and Warner (1995) mention that laziness is associated with resource-rich countries because people have access to easy wealth, eliminating the need to become more productive. A second reason is the fact that abundance of natural resources leads to corruption, rent-seeking and poorer governance. A third reason is the Dutch disease, which claims that natural resources promote deindustrialization. The authors find evidence that resource-rich countries have a higher ratio of the output of the non-tradable sector to the output of the tradable (non-resource) manufacturing sector and production of tradable commodities is concentrated in natural resources rather than in manufacturing. Finally, Sachs and Warner (2001) find evidence that countries rich in natural resources tend to be high-price economies and, partly as a consequence, they tend to miss export-led growth opportunities as well as other kind of growth opportunities. Additionally, high prices tend to attract less efficient producers.

Our results indicate that tariffs affect negatively efficiency $\left(\delta_{3}>0\right)$. Tariffs, as well as nontariff measures, are used by countries to control their imports, with the purpose to protect domestic industries and/or raise fiscal revenues. These measures constitute an obstacle to free trade. Several studies investigate the relationship between trade and

\footnotetext{
${ }^{8}$ It is important to stress that our sample includes only a small and distinct group of developing countries, specifically the emergent economies, which can be considered the most industrialized economies of this group.
} 
productivity growth, namely the diffusion of technology from industrialized countries to less developed countries, the scope of learning-by-exporting, the benefits of trade evaluated by types of trade (imports versus exports), and the types of traded goods that contain more technology (e.g., Isaksson, 2007). One effect of trade liberalization that goes along with our results is the fact that it increases competition, which may encourage firms to reduce inefficiency by pushing them to use inputs more rationally, or, ultimately, force the least inefficient firms to leave the market. Consequently, average productivity of the sector as well as of the economy increases. Many other reasons are behind the result that trade liberalization affects productivity positively, namely the improved access to imported intermediate inputs of higher quality and variety; access to bigger markets, which facilitates the exploitation of scale economies and product specialization; and access to better technology embodied in intermediate and final imported goods. One of the components of trade, imports, is found to have highly significant positive impacts on productivity. Mayer (2001) analyzes imports as a mechanism to introduce foreign (and better) technology into domestic production, which enhances productivity. Isaksson (2001), on the other hand, finds that imports only contribute to the incorporation of better technology into domestic production and, consequently, to the improvement of productivity, if the importer country has the necessary absorptive capacity (for example, the required level of human capital). Acemoglu and Zilibotti (2001) favor this result, by arguing that even if developing countries have access to the same technology by importing it from developed countries, there would still exist differences in productivities due to the inadequacy of this technology to the characteristics of those countries (such as low absorptive capacity measured by the level of human capital).

Although the variable life expectancy is significant only at $12.5 \%$, our results show that health contributes positively to productivity and economic performance, given that higher life expectancy at birth influences efficiency positively $\left(\delta_{4}<0\right)$. Life expectancy at birth is an indicator of the health status of a country. A healthy worker is expected to be more productive and, ceteris paribus, to contribute positively to economic growth. For an analysis of the direct and indirect effects of health on economic performance, see Bloom et al. (2004). Many empirical studies investigate the impact of health on TFP and economic growth (e.g., Cole and Neumayer, 2003; Gallup and Sachs, 2001; Barro and Sala-i-Martin, 1995; Barro, 1997; Knowles and Owen, 1995). Although, in general, authors seem to agree on the importance of health to economic growth, according to 
Knowles and Owen (1995), the significance of this indicator varies across groups of countries. In fact, Knowles and Owen (1995) find that health is a very significant determinant of TFP, except in the case of the OECD countries. A possible reason for life expectancy to be statistically significant only at the $12.5 \%$ level of significance may be the fact that the majority of our sample is composed by OECD countries, which are expected to have similar levels of health standards. Consequently, life expectancy becomes a non-differentiating factor among this group of countries.

A bad business environment, proxied by a high value of the variable time to resolve insolvency, influences efficiency negatively $\left(\delta_{5}>0\right)$. Furthermore, a country with better governance is expected to be more efficient $\left(\delta_{6}<0\right)$, ceteris paribus. The business environment and the governance of a country are defined by its institutions. In fact, good institutions are expected to set a good environment that promotes private investment, productivity and economic growth. Hall and Jones (1999) report that differences in institutions and government policies, which determines the social infrastructure of a country, are responsible for the majority of the differences in physical and human capital accumulation, productivity and output per worker across countries. Given that economic institutions are important to explain differences in economic growth of countries, Acemoglu et al. (2004) try to explain the variety of economic institutions across countries. They conclude that economic institutions determine not only the economic performance of a country but also the distribution of income among the different groups in the society. Thus, this will generate winners and losers and the choice of economic institutions is dependent on the political power of each of these groups. The distribution of the political power is then determined by political institutions (which allocate de jure political power) and the distribution of resources (which allocate de facto political power). Good economic institutions emerge when political institutions (i) allocate power to groups with interests in a broad-based property rights enforcement, (ii) impose real constraints on powerholders, and (iii) when there are relatively few rents to be captured by power-holders (Acemoglu et al., 2004). Several other studies indicate the importance of institutions on TFP and economic growth, which support our results (e.g., Easterly and Levine, 2001; Rodrik et al., 2004; Doucouliagos and Ulubaşoğlu, 2008; Afonso and St. Aubyn, 2013; Christie, 2014; Hu et al., 2014; Bayraktar and Moreno-Dodson, 2015). 
It is widely accepted that innovation contributes positively to TFP and economic performance, evaluated both in levels and growth rates (e.g., Guellec and van Pottelsberghe de la Potterie, 2001; Ulku, 2004; Abdih and Joutz, 2005; Hu et al.,2014). However, our results indicate that patents influence efficiency negatively $\left(\delta_{7}>0\right)$, though with a very small magnitude. Two questions immediately arise from this result: Do patents really provide an incentive to innovate? Are patents a good proxy of innovation? Hall (2007) answers the first question by presenting new reasons why patents may in fact disincentive innovation, which contradicts the traditional view on patents. The traditional view supports the idea that patents encourage innovation. In fact, the inventor, by patenting its invention, is excluding others from using his/her invention for a limited time period, in exchange for revealing the description and implementation of the invention. This would, on one hand, incentive innovation, given that it prevents immediate imitation, and, on the other hand, the sharing of the invention's secrets would help others to innovate more easily, based on the knowledge contained in the innovation. Instead, the idea that patents may discourage innovation is based on the fact that they tend to "increase the costs for subsequent innovators, especially when these innovators need to combine inventions from many sources" (Hall, 2007, pp. 6). The second question has been addressed by a few authors (e.g., Griliches, 1991; Breschi and Lissoni, 2001; Thompson and Fox-Kean, 2005; Shearmur, 2012), who state that using patents as a proxy of innovation may be problematic for a number of reasons: patents only register major product innovations, large firms may choose to patent for precaution (i.e. they may patent inventions that they don't have the intention to place in the market just to keep others from doing it), small firms may choose not to divulge the secrets of their inventions or, simply, may not have the necessary means to acquire a patent. Notice that small firms tend to be the type of firms that are most associated with innovation (e.g., Hall et al., 2009) and, therefore, using patents as its proxy may be truly misleading.

Urbanization shows up in our model as statistically insignificant, although with the expected sign $\left(\delta_{8}<0\right) .{ }^{9}$ Empirical studies have shown that urbanization has a positive influence on TFP and economic growth through agglomeration effects, which contribute to the reduction of transaction costs and creation of economies of scale (Kumar and Kober, 2012). Indirectly, urbanization can be seen as a determinant of TFP growth, given that it favors the concentration of innovative activities and innovation (Shearmur, 2012),

\footnotetext{
${ }^{9}$ Our sample is not an ideal one to investigate the effects of urbanization.
} 
which, as previously mentioned, is an important determinant of TFP growth. In fact, cities are conducive to the concentration of very diverse economic agents as well as a very diverse "ethnic, cultural and social fabric" (Shearmur, 2012), which are pre-requirements for innovation.

Government debt is shown to have a negative impact on efficiency $\left(\delta_{9}>0\right)$. Countries with lower government debt are expected to be closer to the frontier, ceteris paribus. Some studies (e.g., Pattillo et al., 2002; Schclarek, 2004; Checherita-Westphal and Rother, 2010) analyze the relationship between government debt and TFP growth and, hence, economic growth. In particular, Pattillo et al. (2002) find that the quality, rather than the level, of investment is an important channel through which growth is negatively affected by high levels of government debt. Specifically, the expectation of higher future taxation needed to repay the debt may distort the investment decisions towards, for example, short-run projects with a lower positive impact on productivity growth and, consequently, on economic growth. ${ }^{10}$

The effect of the financial crisis on the efficiency of the 27-EU countries is negative, given that $\delta_{10}>0$. Balakrishnan (2009), in particular, analyzes the impact of 88 banking crises on medium-term output growth, over the past 40 years for a large sample of countries. This study reports a persistent and substantive decrease of output after the banking crises. TFP is pointed out as the main responsible for the output losses observed in the short-run, although it recovers to pre-crisis levels in the medium-run. Nevertheless, Balakrishnan (2009) indicates some positive effects of the crises on TFP, which magnitude is not sufficient to overcome the negative effects. The negative effects are related to the more precautious attitude of the financial system in allocating funds, which may not be willing to lend resources to more productive and high-return but more risky projects. Notice that financial crises also have a negative impact on factor accumulation, given that funds available to invest decline. Additionally, less innovation associated with cuts in research and development may have negative impacts on productivity. Finally, lack of financing may affect high-productivity firms, which may be obliged to leave the market or to contract their operations. The positive effects of the crises on TFP are related

\footnotetext{
${ }^{10}$ The anticipation of higher future taxation by the taxpayers and the consequent increase on their savings is known as the "Ricardian equivalence".
} 
to a cleansing effect, where less efficient firms are forced to adopt more efficient practices, or even been forced to leave the market.

Time is an important factor to explain differences in technical inefficiency across countries during 2001-2011, given that $\delta_{11}$, is highly significant. The negative estimate of the time trend coefficient implies a positive evolution of the technical efficiency over time. This result is consistent with the findings of other empirical studies (e.g., Pires and Garcia, 2012).

One last note on the determinants of inefficiency: no variable reflecting labor quality of each country is included in the technical inefficiency model. A labor force with a high degree of human capital (for example in the form of high levels of education) is expected to better acquire and use relevant knowledge. In fact, it is a crucial determinant of a country's ability to innovate (Romer, 1990) and, especially for developing and least developed countries, it influences their capacity to adopt foreign technology, mainly developed in OECD economies, given that "many technologies are designed to make optimal use of the skills of these richer countries' workforce" (Acemoglu and Zilibotti, 2001, pp. 563). Although, human capital is an essential variable, we do not include it in the inefficiency model, due to the fact that labor quality, measured as the index of human capital, is already incorporated in the stochastic production frontier production. Consequently, human capital influences directly the position of the stochastic frontier, rather than the position of the country in relation to the frontier.

\section{IV.3 Technical efficiency and returns to scale}

A ranking of countries based on technical efficiency and returns to scale (RTS) is presented in Table 5. ${ }^{11}$ Technical efficiency and returns to scale for each country are average values calculated for the overall period. Regarding the technical efficiency ranking, no country is fully efficient. The top of the ranking is occupied by European countries, led by Ireland. The bottom of the ranking is occupied by the emergent economies, as expected, where the less efficient country in the sample is Indonesia. South Africa is the only emergent country occupying the $30^{\text {th }}$ position in the ranking, surpassing Slovenia, Portugal, Japan, Hungary and Czech Republic. This position may be explained

\footnotetext{
${ }^{11}$ More detailed information regarding efficiency level per country in each year as well as output elasticities with respect to human and physical capital and average elasticity per country are presented in Appendix C.
} 
by the relative low contribution of agriculture to the economy in comparison to the important contribution of more productive sectors, such as a well-developed manufacturing sector (agriculture value added corresponds to 3\% of GDP in comparison to the $10 \%$ for the group of emergent economies). In addition, South Africa has a relatively good business environment, where the time necessary to resolve insolvency is approximately 2 years, in comparison to 3 years and 3 months for the emergent economies. Finally, the average number of resident patents applications per year in South Africa is one of the lowest in the sample. A somewhat surprising position is the one occupied by the United States, which assumes the $18^{\text {th }}$ position in the ranking. A deeper analysis of the data indicates that the middle position that the United States occupies may be due to (i) the relatively high contribution of the natural resources rents to the economy, which is somewhat close to the OECD average (natural resources are responsible for approximately $1.4 \%$ of the American GDP versus $2.1 \%$ for the OECD countries); (ii) the relatively high level of protectionism, where the average tariff is $1.7 \%$ versus $2.3 \%$ for the OECD countries and $1.85 \%$ for the overall sample; (iii) the "just slightly" higher life expectancy than the OECD average (77.73 versus 76.91 years); (iv) the extremely high number of resident patents applications in comparison to the OECD average (215.000 versus 25.500 patents, respectively); and (v) the relatively high level of government debt (52\% versus $54 \%$ for the OECD countries). Therefore, the United States performance, evaluated in terms of the previous indicators, is close to the OECD average performance, which contradicts what we initially expected, that is, the United States occupying the top positions of the OECD ranking. Finally, Portugal shows up in the $32^{\text {nd }}$ position out of 40 , with a lower technical efficiency score than the sample average. The main drivers of the low technical efficiency of Portugal seem to be the low levels of governance (an average of 1.07 versus 1.3 for the OECD countries) and the high levels of public debt $(74.5 \%$ versus 54\% for the OECD countries). According to the OECD 2013 publication "Portugal: Reforming the State to promote growth", Portugal lacks an efficient public sector capable of promoting a business environment that is more favorable to investment, job creation and innovation, in order to ensure a stronger private sector development. Additionally, Portugal needs institutional reforms that encompass greater sustainability of fiscal management.

TABLE 5

\begin{tabular}{l|lr|rr}
\multicolumn{4}{c}{ Rankings based on technical efficiency and returns to scale } \\
\hline Rank & Country & TE & Country & RTS \\
\hline
\end{tabular}




\begin{tabular}{|c|c|c|c|c|}
\hline 1 & Ireland & 0.89 & South Africa & 1.29 \\
\hline 2 & Norway & 0.83 & Czech Republic & 1.24 \\
\hline 3 & Luxembourg & 0.82 & Indonesia & 1.20 \\
\hline 4 & United Kingdom & 0.82 & Luxembourg & 1.14 \\
\hline 5 & Sweden & 0.78 & Switzerland & 1.12 \\
\hline 6 & Canada & 0.76 & Finland & 1.09 \\
\hline 7 & Netherlands & 0.75 & Norway & 1.09 \\
\hline 8 & Belgium & 0.75 & Spain & 1.06 \\
\hline 9 & Switzerland & 0.74 & Israel & 1.04 \\
\hline 10 & Austria & 0.74 & Mexico & 1.00 \\
\hline 11 & Denmark & 0.72 & Brazil & 0.98 \\
\hline 12 & Finland & 0.72 & Belgium & 0.97 \\
\hline 13 & New Zealand & 0.71 & Germany & 0.96 \\
\hline 14 & France & 0.71 & Japan & 0.94 \\
\hline 15 & Australia & 0.70 & United Kingdom & 0.94 \\
\hline 16 & Germany & 0.70 & Sweden & 0.93 \\
\hline 17 & Israel & 0.70 & Austria & 0.91 \\
\hline 18 & United States & 0.70 & Turkey & 0.89 \\
\hline 19 & Italy & 0.68 & Denmark & 0.89 \\
\hline 20 & Spain & 0.68 & New Zealand & 0.87 \\
\hline 21 & Iceland & 0.65 & Italy & 0.86 \\
\hline 22 & Poland & 0.65 & France & 0.86 \\
\hline 23 & Estonia & 0.63 & Ireland & 0.86 \\
\hline 24 & Greece & 0.63 & India & 0.83 \\
\hline 25 & Mexico & 0.61 & Korea, Rep, & 0.83 \\
\hline 26 & Chile & 0.60 & Estonia & 0.81 \\
\hline 27 & Slovak Republic & 0.60 & Slovak Republic & 0.78 \\
\hline 28 & Korea, Rep. & 0.59 & Netherlands & 0.76 \\
\hline 29 & Turkey & 0.59 & Iceland & 0.73 \\
\hline 30 & South Africa & 0.59 & Portugal & 0.71 \\
\hline 31 & Slovenia & 0.58 & China & 0.70 \\
\hline 32 & Portugal & 0.58 & Hungary & 0.59 \\
\hline 33 & Japan & 0.58 & United States & 0.59 \\
\hline 34 & Hungary & 0.57 & Slovenia & 0.52 \\
\hline 35 & Czech Republic & 0.53 & Australia & 0.50 \\
\hline 36 & Russian Federation & 0.48 & Chile & 0.45 \\
\hline 37 & Brazil & 0.39 & Canada & 0.43 \\
\hline 38 & China & 0.37 & Greece & 0.34 \\
\hline 39 & India & 0.30 & Poland & 0.31 \\
\hline 40 & Indonesia & 0.29 & Russian Federation & 0.22 \\
\hline \multicolumn{2}{|c|}{ Overall Mean } & 0.64 & & 0.83 \\
\hline \multicolumn{2}{|c|}{ OECD Mean } & 0.68 & & 0.82 \\
\hline \multicolumn{2}{|c|}{ Emergent economies Mean } & 0.40 & & 0.87 \\
\hline
\end{tabular}

Regarding the returns to scale ranking, some of the results are intuitive while others are not so intuitive. We expect top positions of the ranking to be occupied by countries that have relatively low levels of physical and human capital per worker, therefore characterized by increasing returns to scale. There are, however, countries that do not fit 
the previous description. A closer analysis allows us to conclude that there are other reasons besides relatively low levels of physical and human capital per worker explaining increasing returns to scale. Specifically, a recent access to EU structural funds (Czech Republic), a very developed financial system (Switzerland), a high degree of innovation (Finland), and the presence of natural resources (Norway, Israel) may be sources of increasing returns in these countries.

Relatively homogeneous European countries, such as Germany, Belgium, United Kingdom, France, Italy, Austria, Ireland and Sweden are concentrated in the middle of the table, with decreasing returns to scale. Those countries conciliate relatively high levels of physical and human capital per worker with high investment in innovation. The bottom positions are occupied by countries with very high levels of human and physical capital per worker (Australia, Canada, United States), with the clear exception of the Russian Federation. The last position occupied by the Russian Federation may be due to the extreme macroeconomic turbulence that characterized this country in the late 1990s, the weak institutional framework and governance, and the fact of being a major oil producer. For the particular case of Portugal, its mid-low position may result from the very low levels of human capital per worker and relatively high levels of physical capital per worker as well as the low level of resources allocated to innovation.

\section{IV.4 Decomposition of TFP change}

Table 6 provides a decomposition of economic growth into total factor accumulation (human and physical capital), change in TFP (technical progress, technical efficiency and scale effects), and random shocks. ${ }^{12}$ Emergent economies grew at a higher annual rate than OECD countries (approximately 4 times higher). This difference results from the fact that total factor accumulation is higher in emergent economies and the random shocks are positive. The random shocks for OECD countries are, on average, significantly negative. The change in TFP is similar for both OECD and emergent economies.

\section{TABLE 6}

Sources of economic growth by groups of countries, 2001-2011

\footnotetext{
12 The sources of economic growth per country are presented in Appendix C.
} 


\begin{tabular}{|c|c|c|}
\hline Variable & Group of Countries & $\begin{array}{c}\text { Compound } \\
\text { Annual \% Rate* }\end{array}$ \\
\hline \multirow{3}{*}{ GDP per worker growth } & OECD Members & 1.20 \\
\hline & Emergent Economies & 4.69 \\
\hline & Difference** & -3.49 \\
\hline \multirow{3}{*}{ a) Total factor accumulation } & OECD Members & 3.54 \\
\hline & Emergent Economies & 3.71 \\
\hline & Difference** & -0.18 \\
\hline \multirow{3}{*}{$\begin{array}{l}\text { a.1) Human capital per worker } \\
\text { accumulation }\end{array}$} & OECD Members & 0.06 \\
\hline & Emergent Economies & 0.19 \\
\hline & Difference & -0.13 \\
\hline \multirow{3}{*}{$\begin{array}{l}\text { a.2) Physical Capital per worker } \\
\text { accumulation }\end{array}$} & OECD Members & 3.48 \\
\hline & Emergent Economies & 3.52 \\
\hline & Difference & -0.04 \\
\hline \multirow{3}{*}{ b) Change in TFP } & OECD Members & 0.29 \\
\hline & Emergent Economies & 0.26 \\
\hline & Difference & 0.03 \\
\hline \multirow{3}{*}{ b.1) Technical change } & OECD Members & -7.07 \\
\hline & Emergent Economies & -7.07 \\
\hline & Difference & 0.00 \\
\hline \multirow{3}{*}{$\begin{array}{l}\text { b.2) Change in technical } \\
\text { efficiency }\end{array}$} & OECD Members & 8.16 \\
\hline & Emergent Economies & 7.67 \\
\hline & Difference & 0.49 \\
\hline \multirow{3}{*}{ b.3) Change in scale effects } & OECD Members & -0.80 \\
\hline & Emergent Economies & -0.34 \\
\hline & Difference & -0.46 \\
\hline \multirow{3}{*}{ c) Random shocks } & OECD Members & -2.62 \\
\hline & Emergent Economies & 0.72 \\
\hline & Difference & -3.34 \\
\hline
\end{tabular}

*This rate is calculated by taking a simple arithmetic mean of the compound annual rates of change of each variable over the countries that constitute each group.

** The difference is calculated in terms of percentage points.

As far as total factor accumulation is concerned, human as well as physical capital per worker accumulation is positive for both groups of economies, although the emergent economies exhibit higher rates of factor accumulation. Physical capital is the main contributor for the economic growth of both groups of countries, but not for the differences observed in the total factor accumulation between groups. This result is associated with the globalization process, in which physical capital can be easily accumulated through external financial resources as well as FDI. Human capital 
accumulation is the main responsible for the difference observed in the total factor accumulation between groups, although with a small impact on economic growth.

Regarding the components of TFP, results indicate that technical change affects both sets of countries in the same manner. As previously mentioned, this result is expected since technological change is Hicks-neutral. Technical efficiency improves over time for both sets of countries, and is approximately outweighed by technological regress. In fact, the improvement of the technical efficiency of countries can be explained, at least in part, by the downward shift of the production frontier. Although technological regress seems counterintuitive, several other studies also report it, even though the time period analyzed is much less controversial than the one in this study (e.g., Rao and Coelli, 1998; Deliktas and Balcilar, 2005; Pires and Garcia, 2012). Since the stochastic production frontier is unique and defined by the OECD countries, technological regress can be explained with globalization and the moving out of firms from OECD countries to other countries, namely emergent economies. Notice that the assumption of a unique production frontier is realistic under our framework given that the concept of Global Value Chains (GVCs) has emerged in the recent past, reflecting the increasing integration of the world's production structure (e.g., Athukorala and Yamashita, 2006; Koopman et al., 2012; Cattaneo et al., 2013). Products are more and more "Made in the World" rather than made in a specific country. ${ }^{13}$ The change in scale effects contributes negatively to the TFP change of both groups of countries, although with a smaller magnitude for the emergent economies. This result, verified in both sets of countries, may be due to the positive rate of factor accumulation combined with decreasing returns to scale.

TFP decomposition, presented in (4)-(10), allows to disentangling the explained part of the economic growth from the unexplained part - the random shocks - where the last component is obtained residually. Results indicate negative and significant random shocks for the OECD countries and positive shocks for the emergent economies.

\section{CONCLUSIONS}

In order to search an answer to the question "Why are some countries far richer than others?", this study attempts to investigate (i) differences in technical efficiency between OECD and emergent economies, (ii) TFP change and its components, (iii) the relative

${ }^{13}$ The World Trade Organization launched the "Made in the World" initiative to better understand trade in the $21^{\text {st }}$ century, strongly characterized by the existence of GVCs. 
importance of TFP change and factor accumulation to economic growth and (iv) the contribution of random shocks to economic growth, obtained as a residual. The analysis is conducted using a stochastic frontier time-varying inefficiency model and a panel of 40 countries, 34 of which are OECD-members and the remaining 6 are emergent economies, for the time period 2001-2011.

Technical efficiency levels are estimated for each country in each year. No country is, on average, fully efficient. Environmental variables are important to explain differences in the technical efficiency levels. Specifically, a high contribution of the agricultural sector to the economy, a high value of natural resources rents, trade barriers, a bad business environment, a high number of patents, a high level of government debt and the financial crisis contribute negatively to technical efficiency. On the other hand, a good health status and good institutions help countries to be located closer to the production frontier.

Economic growth is decomposed into factor accumulation (human and physical capital), TFP change and random shocks. TFP change is decomposed into technical change, technical efficiency change and scale effects, in order to evaluate the contribution of each component to differences in economic performance. The random shocks are obtained residually. Results show that emergent economies exhibit growth rates approximately 4 times higher than the OECD growth rates. Physical capital accumulation is the main contributor for economic growth showing similar rates of change for both groups of countries. Human capital accumulation exhibits higher differences between groups but a smaller impact on growth. Differences in TFP change between groups of countries are not significant. This result is in line with the neoclassical framework and contradicts the results of the recent economic growth literature, which advocates that differences in TFP change are the main contributors to the differences in the growth rate of GDP. Regarding the components of the TFP change, technical change affects both groups of countries in the same manner, resulting from the assumption of Hicks-neutral technological change. Results indicate an improvement of technical efficiency over time for both groups, with the OECD countries surpassing the emergent economies. Yet, technical efficiency change and scale effects are outweighed by technological regress. The technological regress is explained by the downward shift of the frontier of OECD countries - which defines the world frontier - caused by the delocalization of resources from these countries to emergent economies. 
Given that emergent economies perform better in terms of growth rates of GDP per worker and total factor accumulation in 2001-2011, these economies may be under a process of catching up. Or, alternatively, these results may be due to this turbulent decade, which have had particular severe effects on OECD countries. In particular, the random shocks component favors this conclusion, given that these shocks affect the growth of the developed countries negatively. In addition, globalization in the decade means delocalization of firms and their productive activities from OECD countries to emergent economies.

The assumption that there is no technological gap between the OECD and emergent countries in the sample may be strong, leading to an underestimation of the efficiency of emergent countries. Huang et al. (2014) propose a new approach in estimating metafrontier production functions, called the stochastic metafrontier analysis (SMF). This approach is based on a two-step SFA procedure that estimates, in the first step, the groupspecific frontiers and firm's technical efficiency and, in the second step, the metafrontier and group-specific technology gap ratio, both under the SFA framework. This is a very interesting approach that allows separating random shocks from the technology gaps, which in turn can be specified as a function of environmental variables beyond the control of firms.

However, it would not be appropriate to employ SMF in our study. The SMF requires the specification of a group-specific production frontier that may vary across groups and across time and the metafrontier envelops all individual groups' frontiers. The sample, in our study, includes 36 OECD countries and 6 emergent economies in the time period 2001-2011, which would naturally lead to two groups: OECD countries and emergent countries. The number of observations in the emergent economies group is not sufficient to generate reliable results. 


\section{REFERENCES}

Abdih, Y., and Joutz, F. (2005). "Relating the knowledge production function to total factor productivity: an endogenous growth puzzle", IMF Working Paper WP/05/74, Washington, DC: International Monetary Fund.

Abramovitz, M. (1956). "Resource and output trends in the United States since 1870", National Bureau of Economic Research.

Acemoglu, D., Johnson, S., and Robinson, J. (2004). "Institutions as the Fundamental Cause of Long-Run Growth", Working paper No. 10481, National Bureau of Economic Research.

Acemoglu, D., and Zilibotti, F. (2001). "Productivity Differences", The Quarterly Journal of Economics, 116(2), pp. 563-606.

Afonso, A., and St. Aubyn, M. (2013). "Public and Private Inputs in Aggregate Production and Growth: A Cross-country Efficiency Approach", Applied Economics, 45(32), pp. 4487-4502.

Aiyar, S. S. and Feyrer, J. (2002). "A Contribution to the Empirics of Total Factor Productivity", Working Paper No. 02-09, Dartmouth College.

Athukorala, P.-C., and Yamashita, N. (2006). "Production fragmentation and trade integration: East Asia in a global context", The North American Journal of Economics and Finance, 17(3), pp. 233-256.

Balakrishnan, R. (2009). "The transmission of financial stress from advanced to emerging economies", Washington, DC: International Monetary Fund.

Baldwin, J. R., and Gu, W. (2004). "Trade Liberalization: Export-market Participation, Productivity Growth, and Innovation", Oxford Review of Economic Policy, 20(3), pp. 372-392.

Barro, R. J. (1997). Determinants of Economic Growth: A Cross-Country Empirical Study, Cambridge, MA: MIT Press. 
Barro, R. J. (2001). "Human Capital and Growth", The American Economic Review, 91(2), pp. 12-17.

Barro, R. J., and Lee, J. W. (2013). "A New Data Set of Educational Attainment in the World, 1950-2010", Journal of Development Economics, 104(0), pp. 184-198.

Barro, R. J., and Sala-i-Martin, X. (1995). Economic growth, New York: McGraw-Hill.

Battese, G. E., and Coelli, T. J. (1992). "Frontier production functions, technical efficiency and panel data: With application to paddy farmers in India", Journal of Productivity Analysis, 3(1-2), pp. 153-169.

Battese, G. E., and Coelli, T. J. (1995). "A model for technical inefficiency effects in a stochastic frontier production function for panel data", Empirical Economics, 20(2), pp. 325-332.

Bayraktar, N. and Moreno-Dodson, B. (2015). "How Can Public Spending Help You Grow: An Empirical Analysis for Developing Countries", Bulletin of Economic Research, 67:1, pp. 30-64.

Bernard, A. and Jones, C. I. (1996). "Productivity across industries and countries: time series theory and evidence", Review of Economics and Statistics 78(1), pp.13546.

Bloom, D. E., Canning, D. and Sevilla, J. (2004). "The effect of health on economic growth : a production function approach", World Development, 32(1), pp. 1-13.

Breschi, S. and Lissoni, F. (2001). "Knowledge spillovers and local innovation systems : a critical survey", LUIC Papers in Economies No. 84, Cattaneo University.

Cattaneo, O., Gereffi, G., Miroudot, S. and Taglioni, D. (2013). "Joining, upgrading and being competitive in global value chains: a strategic framework", Policy Research Working Paper Series. World Bank

Caselli, F., Esquivel, G., and Lefort, F. (1996). "Reopening the convergence debate: A new look at cross-country growth empirics", Journal of Economic Growth, 1(3), pp. 363-389. 
Chanda, A., and Dalgaard, C.-J. (2008). "Dual Economies and International Total Factor Productivity Differences: Channelling the Impact from Institutions, Trade, and Geography", Economica, 75(300), pp. 629-661.

Checherita-Westphal, C., and Rother, P. (2010). "The impact of high and growing government debt on economic growth: an empirical investigation for the euro area", Working paper No. 1237, European Central Bank.

Cole, M.A. and Neumayer, E. (2003). "The Impact of Poor Health on Total Factor Productivity: An Empirical Investigation", Mimeo, University of Birmingham.

Christie, T. (2014). "The Effect of Government Spending on Economic Growth: Testing the Non-Linear Hypothesis", Bulletin of Economic Research, 66:2, pp. 183-204.

Deliktas, E. and Balcilar, M. (2005). "A comparative analysis of productivity growth, catch-up, and convergence in transition economies", Emerging Markets Finance and Trade, 41(1), pp. 6-28.

Dollar, D., and Kraay, A. (2004). "Trade, Growth, and Poverty", The Economic Journal, 114(493), pp. F22-F49.

Doucouliagos, H., and Ulubaşoğlu, M. A. (2008). "Democracy and Economic Growth: A Meta-Analysis", American Journal of Political Science, 52(1), pp. 61-83.

Easterly, W., and Levine, R. (2001). "What have we learned from a decade of empirical research on growth? It's Not Factor Accumulation: Stylized Facts and Growth Models", The World Bank Economic Review, 15(2), pp. 177-219.

Edwards, S. (1998). "Openness, Productivity and Growth: What do We Really Know?", The Economic Journal, 108(447), pp. 383-398.

Gallup, J. L., and Sachs, J. D. (2001). "The economic burden of malaria", The American Journal of Tropical Medicine and Hygiene, 64(1-2 Suppl), pp. 85-96.

Griliches, Z. (1991). "Patent Statistics as Economic Indicators: A Survey", Working Paper, No. 3301, National Bureau of Economic Research. 
Guellec, D., and van Pottelsberghe de la Potterie, B. (2001). "The Internationalisation of Technology Analysed with Patent Data", Research Policy, 30(8), pp. 1253-1266.

Hall, B., Lotti, F., and Mairesse, J. (2009). "Innovation and productivity in SMEs: empirical evidence for Italy", Small Business Economics, 33(1), pp. 13-33.

Hall, B. H. (2007). "Patents and patent policy", Oxford Review of Economic Policy, 23(4), pp. 568-587.

Hall, R. E., and Jones, C. I. (1999). "Why Do Some Countries Produce So Much More Output Per Worker Than Others?", The Quarterly Journal of Economics, 114(1), pp. 83-116.

Hu, J.L., Yang, C.H. and Chen, C.P. (2014). "R\&D Efficiency and the National Innovation System: An International Comparison using the Distance Function Approach", Bulletin of Economic Research, 66: 1, pp. 55-71.

Huang, C. J., Huang, T.-H., and Liu, N.-H. (2014). "A New Approach to Estimating the Metafrontier Production Function Based on a Stochastic Frontier Framework". Journal of Productivity Analysis, 42, pp. 241-254.

Isaksson, A. (2001). "The Importance of Human Capital for the Trade-Growth Link", Working Paper, No. 2, UNIDO.

Isaksson, A. (2007). "Determinants of total factor productivity: a literature review", Working Paper, No. 2, UNIDO.

Islam, N. (1995). "Growth Empirics: A Panel Data Approach", The Quarterly Journal of Economics, 110(4), pp. 1127-1170.

Jaumotte, F. and Spatafora, N. (2007). Asia rising: a sectoral perspective, Washington, DC: IMF.

Jones, C. I., and Romer, P. M. (2010). "The New Kaldor Facts: Ideas, Institutions, Population, and Human Capital", American Economic Journal: Macroeconomics, 2(1), pp. 224-245. 
Klenow, P. and Rodríguez-Clare, A. (1997). "The neoclassical revival in growth economics : has it gone too far?", National Bureau of Economic Research: 73114.

Knight, M., Loyaza, N. and Villanueva, D. (1993). "Testing the neoclassical theory of economic growth: a panel data approach", International. Monetary Fund, 40(3), pp. 512-541.

Knowles, S., and Owen, P. D. (1995). "Health capital and cross-country variation in income per capita in the Mankiw-Romer-Weil model", Economics Letters, 48(1), pp. 99-106.

Koopman, R., Wang, Z., and Wei, S.-J. (2012). "Estimating domestic content in exports when processing trade is pervasive", Journal of Development Economics, 99(1), pp. 178-189.

Krueger, A., Schiff, M. and Valdés, A. (1988). "Agricultural Incentives in Developing Countries: Measuring the effect of sectoral and economywide policies", The World Bank Economic Review, 2(3), pp. 255-271.

Kumar, A., and Kober, B. (2012). "Urbanization, human capital, and cross-country productivity differences", Economics Letters, 117(1), pp. 14-17.

Kumbhakar, S., Gudbrand, L., and Hardaker, J. B. (2014). "Technical Efficiency in Competing Panel Data Models: A Study of Norwegian Grain Farming", Journal of Producitvity Analysis, 41(2), pp. 321-337.

Kumbhakar, S., and Lovell, C. A. K. (2000). Stochastic frontier analysis, Cambridge: Cambridge University Press.

Kumbhakar, S., Wang, H.-J., and Horncastle, A. P. (2015). A Practioner's Guide to Stochastic Frontier Analysis Using Stata, New York: Cambridge University Press.

Kuznets, S. S. (1971). Economic growth of nations: total output and production structure, Belknap Press of Harvard University Press. 
Mankiw, N. G., Romer, D., and Weil, D. N. (1992). "A Contribution to the Empirics of Economic Growth", The Quarterly Journal of Economics, 107(2), pp. 407-437.

Martin, W. and Mitra, D. (2001). "Productivity Growth and Convergence in Agriculture versus Manufacture", Economic Development and Cultural Change, 49(2), pp. 403-422.

Mayer, J. (2001). "Technology Diffusion, Human Capital And Economic Growth In Developing Countries", Discussion Papers, No. 154, UNCTAD.

OECD (1995). "Technological Change and Structural Adjustment in OECD Agriculture", Organization for Economic Co-operation and Development, Paris.

OECD (2013). "Portugal - Reforming the state to promote growth", "Better Policies" Series. Organization for Economic Co-operation and Development, Paris.

Pattillo, C., Poirson, H. and Ricci, L. (2002). "External Debt and Growth", Working paper No.02/69, International Monetary Fund.

Pires, J. O., and Garcia, F., (2012). "Productivity of Nations: A Stochastic Frontier Approach to TFP Decomposition", Economics Research International, vol. 2012, article ID 584869.

Prebisch, R. (1984). "Five stages in my thinking about economic development", Oxford University Press for the World Bank.

Psacharopoulos, G. (1994). "Returns to Investment in Education: A Global Update", World Development, 22(9), pp. 1325-1343.

Rao, D. S. P. and Coelli, T. J. (1998). "A cross-country analysis of GDP growth catch-up and convergence in productivity and inequality", Working Paper 5/98, Centre for Efficiency and Productivity Analysis (CEPA).

Restuccia, D., Yang, D. and Zhu, X. (2008). "Agriculture and Aggregate Productivity: A quantitative cross-country analysis", Journal of Monetary Economics, 55, pp. 234250 
Rodrik, D., Subramanian, A., and Trebbi, F. (2004). "Institutions Rule: The Primacy of Institutions Over Geography and Integration in Economic Development", Journal of Economic Growth, 9(2), pp. 131-165.

Romer, P. M. (1990). "Human capital and growth: Theory and evidence", CarnegieRochester Conference Series on Public Policy, 32(0), pp. 251-286.

Sachs, J. D., and Warner, A. M. (1995). "Natural Resource Abundance and Economic Growth", National Bureau of Economic Research Working Paper Series, No. 5398.

Sachs, J. D., and Warner, A. M. (2001). "The curse of natural resources", European Economic Review, 45(4-6), pp. 827-838.

Schclarek, A. (2004). "Debt and Economic Growth in Developing and Industrial Countries", Working paper, Lund University, Department of Economics.

Shearmur, R. (2012). "Are cities the font of innovation? A critical review of the literature on cities and innovation", Cities, 29, Supplement 2(0), pp. S9-S18.

Solow, R. M. (1956). "A Contribution to the Theory of Economic Growth", The Quarterly Journal of Economics, 70(1), pp. 65-94.

Solow, R. M. (1957). "Technical Change and the Aggregate Production Function", Review of Economics and Statistics, 39(3), pp. 313-320.

Thompson, P., and Fox-Kean, M. (2005). "Patent Citations and the Geography of Knowledge Spillovers: A Reassessment", The American Economic Review, 95(1), pp. 450-460.

Ulku, H. (2004). "R and D, Innovation, and Economic Growth: An Empirical Analysis", International Monetary Fund.

Young, A. (1995). "The Tyranny of Numbers: Confronting the Statistical Realities of the East Asian Growth Experience", The Quarterly Journal of Economics, 110(3), pp. 641-680. 


\section{APPENDIX A}

\section{Likelihood Ratio Tests}

We test for (i) the translog functional form where $\mathrm{H}_{\mathrm{o}}$ is the Cobb-Douglas functional form with $\beta_{t t}=\beta_{K t}=\beta_{L t}=\beta_{K L}=\beta_{K K}=\beta_{L L}=0$; (ii) the existence of technological progress, with $\beta_{t}=\beta_{t t}=\beta_{K t}=\beta_{L t}=0$ as the null hypothesis; (iii) the type of technological progress, where $\beta_{K t}=0$ is the $\mathrm{H}_{\mathrm{o}}$ for Harrod-neutral technological progress, $\beta_{L t}=0$ is the $\mathrm{H}_{\mathrm{o}}$ for Solow neutral technological progress and $\beta_{K t}=\beta_{L t}=0$ is the $\mathrm{H}_{\mathrm{o}}$ for Hicks neutral technological progress; (iv) the technical inefficiency being a linear function of the country-specific variables, where $\mathrm{H}_{\mathrm{o}}$ is $\delta_{0}=\delta_{1}=\delta_{2}=\delta_{3}=$ $\delta_{4}=\delta_{5}=\delta_{6}=\delta_{7}=\delta_{8}=\delta_{9}=\delta_{10}=\delta_{11}=0$; (v) combinations of the previous restrictions. The results of these tests are presented in the next table. In addition, the presence of technical inefficiency in the model is tested by setting $\mathrm{H}_{\mathrm{o}}$ equal to $\delta_{0}=\delta_{1}=$ $\delta_{2}=\delta_{3}=\delta_{4}=\delta_{5}=\delta_{6}=\delta_{7}=\delta_{8}=\delta_{9}=\delta_{10}=\delta_{11}=\sigma_{u}=\sigma_{v}$. The presence of stochastic inefficiency effects is tested by restricting $\sigma_{u}=\sigma_{v}=0$, which, by looking at the corresponding t-statistics, allows us to reject the null hypothesis. 


\begin{tabular}{|c|c|c|c|c|c|c|c|}
\hline Model & Full translog & Harrod Neutral & Solow Neutral & Hicks Neutral & $\begin{array}{c}\text { Translog } \\
\text { without TP }\end{array}$ & $\begin{array}{c}\text { Cobb-Douglas } \\
\text { with TP } \\
\end{array}$ & $\begin{array}{c}\text { Translog without } \\
\text { Inefficiency }\end{array}$ \\
\hline $\begin{array}{l}\text { Harrod Neutral } \\
\beta_{K t}=0\end{array}$ & $\begin{array}{c}0.04 \\
\chi^{2}(1)=3.84^{* *}\end{array}$ & - & _ & 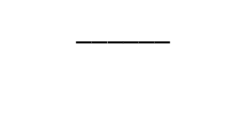 & - & - & \\
\hline $\begin{array}{l}\text { Solow Neutral } \\
\beta_{L t}=0\end{array}$ & $\begin{array}{c}1.88 \\
\chi^{2}(1)=3.84^{* *}\end{array}$ & NC & - & - & - & & \\
\hline $\begin{array}{l}\text { Hicks Neutral } \\
\beta_{K t}=\beta_{L t}=0\end{array}$ & $\begin{array}{c}2.71 \\
\chi^{2}(2)=5.99^{* *}\end{array}$ & $\begin{array}{c}2.68 \\
\chi^{2}(1)=3.84^{* *}\end{array}$ & $\begin{array}{c}0.83 \\
\chi^{2}(1)=3.84^{* *}\end{array}$ & & - & & \\
\hline $\begin{array}{l}\text { Translog without TP } \\
\beta_{t}=\beta_{t t}=\beta_{K t}=\beta_{L t}=0\end{array}$ & $\begin{array}{c}11.6^{*} \\
\chi^{2}(5)=11.07^{* *}\end{array}$ & $\begin{array}{c}11.56^{*} \\
\chi^{2}(4)=9.49^{* *}\end{array}$ & $\begin{array}{c}9.72^{*} \\
\chi^{2}(4)=9.49^{* *}\end{array}$ & $\begin{array}{c}8.89^{*} \\
\chi^{2}(3)=7.81^{* *}\end{array}$ & - & - & \\
\hline $\begin{array}{l}\text { Cobb-Douglas with TP } \\
\beta_{t t}=\beta_{K t}=\beta_{L t}=\beta_{K L}=\beta_{K K}=\beta_{L L}=0\end{array}$ & $\begin{array}{c}91.5^{*} \\
\chi^{2}(6)=12.59^{* *}\end{array}$ & $\begin{array}{l}91.46^{*} \\
\chi^{2}(5)= \\
11.07^{* *}\end{array}$ & $\begin{array}{c}89.62^{*} \\
\chi^{2}(5)=11.07^{* *}\end{array}$ & $\begin{array}{c}88.78^{*} \\
\chi^{2}(4)=9.49^{* *}\end{array}$ & $\mathrm{NC}$ & & \\
\hline $\begin{array}{l}\text { Cobb-Douglas without TP } \\
\beta_{t}=\beta_{t t}=\beta_{K t}=\beta_{L t}=\beta_{K L}=\beta_{K K}=\beta_{L L}=0\end{array}$ & $\begin{array}{c}96.25^{*} \\
\chi^{2}(8)=15.51^{* *}\end{array}$ & $\begin{array}{l}96.21^{*} \\
\chi^{2}(7)= \\
14.07^{* *}\end{array}$ & $\begin{array}{c}94.37^{*} \\
\chi^{2}(7)=14.07^{* *}\end{array}$ & $\begin{array}{c}93.54^{*} \\
\chi^{2}(6)=12.59^{* *}\end{array}$ & $\begin{array}{c}84.65^{*} \\
\chi^{2}(3)=7.81^{* *}\end{array}$ & $\begin{array}{c}4.75 \\
\chi^{2}(2)=5.99^{* *}\end{array}$ & \\
\hline $\begin{array}{l}\text { Translog with Inefficiency not being a linear } \\
\text { function of z-variables } \\
\begin{aligned} \delta_{0}=\delta_{1}=\delta_{2}=\delta_{3} & =\delta_{4}=\delta_{5}=\delta_{6}=\delta_{7}=\delta_{8}=\delta_{9} \\
& =\delta_{10}=\delta_{11}=0\end{aligned}\end{array}$ & $\begin{array}{c}231.79^{*} \\
\chi^{2}(11)=19.68^{* *}\end{array}$ & NC & $\mathrm{NC}$ & NC & NC & - & \\
\hline $\begin{array}{l}\text { Hicks Neutral with Inefficiency not being a } \\
\text { linear function of z-variables } \\
\qquad \begin{aligned} \beta_{K t}=\beta_{L t}=\delta_{0}= & \delta_{1}=\delta_{2}=\delta_{3}=\delta_{4}=\delta_{5}=\delta_{6} \\
& =\delta_{7}=\delta_{8}=\delta_{9}=\delta_{10}=\delta_{11} \\
& =0\end{aligned}\end{array}$ & $\begin{array}{c}231.73^{*} \\
\chi^{2}(13)=22.36^{* *}\end{array}$ & $\mathrm{NC}$ & NC & $\begin{array}{c}229.02^{*} \\
\chi^{2}(11)= \\
19.68^{* *}\end{array}$ & NC & NC & $\begin{array}{c}0.24 \\
\chi^{2}(2)=5.99^{* *}\end{array}$ \\
\hline
\end{tabular}

* An asterisk on the value of the test statistic indicates that it exceeds the corresponding critical value of the test statistic at the $5 \%$ level of significance for the $\chi^{2}$-distribution and so the null hypothesis is rejected

** Two asterisks indicates the critical value of the test statistic at the $5 \%$ level of significance for the $\chi^{2}$-distribution 


\section{APPENDIX B}

Elasticity of substitution

The Allen partial elasticity of substitution (AES) between human per worker $h$ and physical capital per worker $k$ is given by

$$
\sigma_{h k}=\frac{f_{h} x_{h}+f_{k} x_{k}}{x_{h} x_{k}} \frac{F_{h k}}{F}
$$

where $F$ is the determinant of the bordered hessian matrix, $F_{h k}$ is the cofactor of $f_{h k}$, and $f_{h}$ and $f_{k}$ are the first partial derivatives of the production function $\mathrm{f}($.$) with respect to$ inputs $\mathrm{h}$ and $\mathrm{k}$, respectively.

Given that $\sigma_{h k}$ depends on the quantity of the input factors, the elasticity of substitution is calculated at the sample mean. The estimated bordered hessian matrix is:

$$
\left[\begin{array}{ccc}
0 & 0.4322 & 0.18262 \\
0.4322 & 2.3916 & 0.07903 \\
0.18262 & 0.07903 & -0.0096
\end{array}\right]
$$

Substituting the values in the matrix into $\sigma_{h k}$, we obtain an elasticity of substitution of 0.1 , indicating that human and physical capital per worker are substitutes. 


\section{APPENDIX C}

TABLE C. 1

Efficiency levels by country and by group of countries, 2001-2011

\begin{tabular}{|c|c|c|c|c|c|c|c|c|c|c|c|c|}
\hline Country & 2001 & 2002 & 2003 & 2004 & 2005 & 2006 & 2007 & 2008 & 2009 & 2010 & 2011 & Mean \\
\hline Australia & 0.46 & 0.52 & 0.59 & 0.62 & 0.67 & 0.70 & 0.75 & 0.78 & 0.82 & 0.88 & 0.91 & 0.70 \\
\hline Austria & 50 & 0.57 & 0.62 & 0.67 & 0.72 & 0.77 & 0.81 & .84 & 0.83 & 0.88 & 0.90 & .74 \\
\hline $\mathrm{Be}$ & 53 & 0.60 & 0.65 & 0.69 & 0.73 & 0.76 & 0.81 & .84 & 0.83 & 0.88 & 0.88 & 0.75 \\
\hline Brazil & 30 & 0.30 & 0.27 & 0.29 & 0.31 & 0.38 & 0.41 & 0.45 & 0.48 & 0.52 & 0.55 & 0.39 \\
\hline C & .53 & 0.58 & 0.63 & 0.69 & 0.74 & 0.77 & 0.82 & 0.85 & 0.87 & 0.92 & 0.93 & 0.76 \\
\hline Chile & 41 & 0.44 & 0.46 & 0.50 & 0.54 & 0.62 & 0.66 & 0.70 & 0.71 & 0.76 & 0.81 & 0.60 \\
\hline China & 27 & 0.29 & 0.31 & 0.32 & 0.35 & 0.37 & 0.40 & 0.40 & 0.43 & 0.44 & 0.44 & 0.37 \\
\hline Czec & 41 & 0.45 & 0.41 & 0.44 & 0.47 & 0.49 & 0.55 & 0.58 & 0.59 & 0.68 & 0.70 & 0.53 \\
\hline Denı & 50 & 0.57 & 0.59 & 0.64 & 0.68 & 0.73 & 0.81 & 0.84 & 0.83 & 0.88 & 0.91 & 0.72 \\
\hline Esto & 47 & 0.56 & 0.57 & 0.59 & 0.62 & 0.65 & 0.68 & 0.68 & 0.66 & 0.70 & 0.76 & 0.63 \\
\hline & 49 & 0.56 & 0.61 & 0.66 & 0.69 & 0.74 & 0.79 & 0.83 & 0.80 & 0.87 & 0.90 & 0.72 \\
\hline France & 54 & 0.59 & 0.62 & 0.64 & 0.68 & 0.71 & 0.75 & 0.79 & 0.79 & 0.83 & 0.87 & 0.71 \\
\hline & 50 & 0.55 & 0.60 & 0.63 & 0.67 & 0.72 & 0.76 & 0.79 & 0.77 & 0.85 & 0.87 & 0.70 \\
\hline Greece & 0.47 & 0.52 & 0.55 & 0.58 & 0.61 & 0.64 & 0.66 & 0.70 & 0.70 & 0.74 & 0.77 & 0.63 \\
\hline & 42 & 0.49 & 0.51 & 0.54 & 0.58 & 0.60 & 0.60 & 0.61 & 0.61 & 0.65 & 0.69 & 0.57 \\
\hline Icelan & 0.44 & 0.49 & 0.52 & 0.59 & 0.62 & 0.63 & 0.67 & 0.72 & 0.75 & 0.84 & 0.89 & 0.65 \\
\hline India & 19 & 0.22 & 0.24 & 0.22 & 0.26 & 0.30 & 0.32 & 0.33 & 0.36 & 0.41 & 0.43 & 30 \\
\hline Indon & 0.23 & 0.22 & 0.22 & 0.23 & 0.25 & 0.27 & 0.29 & 0.33 & 0.35 & 0.38 & 0.41 & 0.29 \\
\hline Irol & 66 & 0.78 & 0.88 & 0.91 & 0.94 & 0.93 & 0.93 & 0.94 & 0.93 & 0.94 & 0.96 & 0.89 \\
\hline Israel & 0.50 & 0.54 & 0.56 & 0.60 & 0.65 & 0.70 & 0.75 & 0.78 & 0.82 & 0.88 & 0.91 & 0.70 \\
\hline Italy & .51 & 0.54 & 0.58 & 0.61 & 0.64 & 0.68 & 0.72 & 0.77 & 0.76 & 0.82 & 0.84 & 0.68 \\
\hline Japan & 40 & 0.43 & 0.49 & 0.53 & 0.54 & 0.57 & 0.60 & 0.64 & 0.66 & 0.73 & 0.76 & 0.58 \\
\hline Kore & 45 & 0.47 & 0.52 & 0.52 & 0.56 & 0.57 & 0.60 & 0.65 & 0.65 & 0.71 & 0.78 & 0.59 \\
\hline Luxe & 60 & 0.68 & 0.72 & 0.74 & 0.81 & 0.86 & 0.92 & 0.90 & 0.90 & 0.94 & 0.95 & 0.82 \\
\hline Mexico & .44 & 0.49 & 0.47 & 0.52 & 0.57 & 0.60 & 0.64 & 0.67 & 0.69 & 0.77 & 0.82 & 0.61 \\
\hline Neth & 54 & 0.60 & 0.64 & 0.68 & 0.74 & 0.77 & 0.82 & 0.85 & 0.84 & 0.88 & 0.91 & 0.75 \\
\hline New & .47 & 0.52 & 0.57 & 0.61 & 0.66 & 0.67 & 0.78 & 0.82 & 0.88 & 0.91 & 0.93 & 0.71 \\
\hline Norway & 59 & 0.62 & 0.69 & 0.76 & 0.84 & 0.88 & 0.90 & 0.93 & 0.94 & 0.96 & 0.97 & 0.83 \\
\hline Poland & .43 & 0.47 & 0.50 & 0.53 & 0.58 & 0.63 & 0.71 & 0.76 & 0.79 & 0.84 & 0.88 & 0.65 \\
\hline & .43 & 0.46 & 0.48 & 0.51 & 0.56 & 0.59 & 0.63 & 0.66 & 0.66 & 0.69 & 0.72 & 0.58 \\
\hline Russi & 0.24 & 0.27 & 0.31 & 0.36 & 0.39 & 0.47 & 0.53 & 0.58 & 0.62 & 0.70 & 0.74 & 0.48 \\
\hline Slovak R & 0.43 & 0.47 & 0.47 & 0.50 & 0.55 & 0.60 & 0.63 & 0.68 & 0.69 & 0.74 & 0.79 & 0.60 \\
\hline Slovenia & 0.42 & 0.47 & 0.51 & 0.52 & 0.55 & 0.58 & 0.63 & 0.66 & 0.66 & 0.69 & 0.71 & 0.58 \\
\hline South & 0.41 & 0.45 & 0.49 & 0.51 & 0.56 & 0.59 & 0.62 & 0.64 & 0.68 & 0.73 & 0.77 & 0.59 \\
\hline Spain & 0.50 & 0.55 & 0.58 & 0.61 & 0.65 & 0.68 & 0.70 & 0.75 & 0.76 & 0.80 & 0.84 & 0.68 \\
\hline Sweden & 0.55 & 0.62 & 0.67 & 0.74 & 0.79 & 0.81 & 0.84 & 0.87 & 0.86 & 0.91 & 0.94 & 0.78 \\
\hline Switzerland & 0.51 & 0.59 & 0.61 & 0.67 & 0.70 & 0.73 & 0.78 & 0.84 & 0.87 & 0.93 & 0.94 & 0.74 \\
\hline Turkey & 0.40 & 0.44 & 0.45 & 0.50 & 0.56 & 0.58 & 0.61 & 0.65 & 0.70 & 0.76 & 0.81 & 0.59 \\
\hline United Kingdom & 0.59 & 0.67 & 0.73 & 0.77 & 0.81 & 0.86 & 0.90 & 0.91 & 0.89 & 0.92 & 0.93 & 0.82 \\
\hline United & 0.49 & 0.54 & 0.58 & 0.62 & 0.66 & 0.70 & 0.73 & 0.77 & 0.82 & 0.87 & 0.91 & 0.70 \\
\hline Mean & 0.46 & 0.51 & 0.54 & 0.57 & 0.61 & 0.65 & 0.69 & 0.72 & 0.73 & 0.78 & 0.81 & 0.64 \\
\hline OECD Mean & 0.49 & 0.54 & 0.58 & 0.62 & 0.66 & 0.69 & 0.73 & 0.77 & 0.77 & 0.82 & 0.86 & 0.68 \\
\hline Non-OECD Mean & 0.27 & 0.29 & 0.30 & 0.32 & 0.35 & 0.40 & 0.43 & 0.46 & 0.49 & 0.53 & 0.56 & 0.40 \\
\hline
\end{tabular}


TABLE C.2

Output elasticity with respect to human capital, 2001-2011

\begin{tabular}{|c|c|c|c|c|c|c|c|c|c|c|c|}
\hline Country & 2001 & 2002 & 2003 & 2004 & 2005 & 2006 & 2007 & 2008 & 2009 & 2010 & 2011 \\
\hline Australia & -1.00 & 0.47 & 0.57 & -1.80 & 0.72 & 0.69 & 0.36 & 0.53 & -0.11 & 0.30 & -2.15 \\
\hline Austria & -1.45 & 0.48 & 0.15 & 0.45 & 0.34 & 1.02 & 0.26 & 0.98 & -0.13 & 0.59 & 0.40 \\
\hline Belgium & -0.01 & 0.51 & 0.27 & 1.11 & 0.72 & 0.50 & -0.94 & -1.09 & 1.28 & 0.99 & 0.79 \\
\hline Brazil & 1.01 & 0.43 & 0.68 & 1.04 & 1.12 & 0.69 & 0.55 & -1.91 & 1.13 & -1.07 & 0.18 \\
\hline Canada & -1.02 & 0.60 & 0.51 & -2.86 & 0.91 & -0.24 & 0.67 & -1.00 & 0.77 & -1.13 & 0.60 \\
\hline Chile & -1.44 & 0.71 & 0.47 & 0.79 & 1.20 & 0.71 & -2.59 & -1.09 & 0.82 & -1.47 & 0.40 \\
\hline China & -1.36 & 0.93 & 0.72 & 0.36 & -2.11 & 0.72 & 0.33 & 0.48 & 0.29 & 0.95 & 0.52 \\
\hline Czech Re & 0.89 & 0.07 & 0.38 & 0.78 & 0.63 & 1.19 & 0.32 & 1.12 & 0.76 & 0.84 & 0.93 \\
\hline Denmark & -0.80 & 0.28 & 0.43 & -0.32 & 0.40 & 1.17 & 0.33 & 0.80 & 1.10 & 0.72 & -1.01 \\
\hline Estonia & 0.95 & 0.08 & 0.33 & -1.42 & 0.30 & 0.45 & 0.03 & 1.06 & 1.14 & 0.64 & -1.22 \\
\hline Finland & 0.56 & 0.70 & 0.70 & -1.14 & 0.24 & 0.85 & 1.04 & 0.95 & 0.65 & 0.60 & 0.58 \\
\hline France & 1.02 & 0.52 & -2.47 & -1.50 & 0.46 & 0.59 & 1.01 & 0.99 & 0.88 & 0.56 & 0.62 \\
\hline Germ & 0.73 & 0.32 & 0.73 & -2.37 & 0.27 & 0.73 & 0.75 & 0.80 & 0.80 & 0.38 & 0.38 \\
\hline Greece & 0.84 & 0.36 & 0.86 & -3.54 & -0.20 & -3.05 & 0.50 & 0.63 & 0.72 & 0.29 & -1.73 \\
\hline Hungary & -2.68 & 1.07 & 0.80 & 0.52 & 0.73 & -2.71 & 0.87 & 0.68 & 0.85 & 0.74 & -0.24 \\
\hline Iceland & -3.37 & 0.31 & 0.79 & 0.44 & 0.67 & 0.82 & 0.60 & 0.65 & 0.32 & 0.62 & 0.00 \\
\hline India & 0.96 & 0.29 & 0.63 & -0.83 & 1.56 & -1.15 & 0.87 & 1.22 & -0.32 & 1.08 & -1.66 \\
\hline Indonesi & 0.34 & 0.40 & 1.05 & 1.02 & 1.55 & 0.67 & 0.35 & 0.77 & 0.77 & 0.25 & -0.50 \\
\hline Ireland & 0.83 & -0.10 & 0.97 & -1.05 & 1.54 & 0.63 & 1.07 & 0.12 & -0.33 & -2.32 & 0.89 \\
\hline Israel & 0.39 & -0.44 & -0.58 & 0.79 & 1.52 & 1.09 & 0.87 & -0.91 & 0.55 & 1.12 & 0.89 \\
\hline Italy & 0.54 & -0.64 & -0.16 & 0.87 & 1.50 & 0.41 & 0.15 & 0.89 & -0.38 & -1.31 & 0.86 \\
\hline Japan & 0.24 & -0.05 & -0.08 & -1.20 & 1.47 & 0.43 & -0.46 & 0.58 & 0.75 & 1.00 & 0.96 \\
\hline Korea & 0.86 & -0.14 & 1.38 & -1.29 & 1.43 & -2.20 & -0.37 & 0.46 & 0.76 & 0.96 & 0.54 \\
\hline Luxembc & 0.52 & 1.33 & 0.93 & 0.59 & 1.35 & 0.60 & 1.02 & -0.86 & 0.97 & 0.57 & -0.66 \\
\hline Mexico & 0.61 & 0.59 & 0.88 & -0.34 & 1.30 & 0.67 & 0.44 & -0.88 & 0.77 & 0.33 & 0.67 \\
\hline Netherla & 0.43 & 0.60 & -0.48 & 0.77 & 0.35 & 0.71 & 0.31 & -0.91 & -0.79 & 1.08 & 0.28 \\
\hline New Zea & 0.44 & 0.13 & 0.60 & 0.50 & 0.27 & 0.42 & -1.65 & 1.13 & 0.48 & 1.15 & 0.26 \\
\hline Norway & 0.72 & 0.04 & 0.83 & 0.70 & 1.39 & -1.56 & 0.35 & 1.10 & 0.63 & 0.57 & 0.73 \\
\hline Poland & -0.02 & -0.15 & -3.46 & 0.59 & 1.33 & -0.42 & 0.02 & -0.09 & 0.72 & 0.28 & -2.67 \\
\hline Portugal & -0.98 & -0.85 & 0.65 & 0.82 & 0.36 & 0.18 & -0.33 & 0.57 & 0.77 & 0.33 & 0.68 \\
\hline Russian F & 0.97 & -0.96 & -2.76 & 0.73 & 0.21 & -1.21 & -0.69 & 1.37 & 0.46 & -3.16 & 0.55 \\
\hline Slovak Republic & 0.61 & -0.95 & 0.52 & 0.74 & 0.09 & 0.72 & -0.05 & 1.25 & -2.25 & 0.67 & 0.28 \\
\hline Slovenia & -0.83 & -1.19 & -2.85 & 1.09 & -0.04 & 0.63 & -0.06 & 0.51 & 0.63 & 1.10 & 0.26 \\
\hline South Africa & 0.88 & 0.85 & 0.55 & 0.60 & -0.12 & 1.05 & 0.01 & 1.24 & 0.50 & 1.05 & 1.17 \\
\hline Spain & 0.83 & 0.61 & 0.71 & 0.76 & -0.16 & -0.07 & -0.01 & -0.19 & 0.88 & 0.50 & 1.16 \\
\hline Sweden & 0.81 & 0.50 & 0.64 & 0.82 & -0.77 & 0.81 & 0.95 & 1.30 & -3.27 & 0.89 & 1.13 \\
\hline Switzerla & 0.61 & 0.46 & 0.57 & 0.38 & -0.78 & 0.82 & 0.79 & 0.62 & 1.11 & 0.84 & 1.07 \\
\hline Turkey & 0.59 & 0.64 & 1.04 & 0.69 & -0.88 & 0.57 & -2.95 & 1.02 & 1.00 & 0.92 & 1.03 \\
\hline United Kingdom & 0.28 & 0.65 & -0.13 & -0.41 & -0.57 & 0.51 & 0.54 & 0.88 & 0.03 & 0.82 & 1.01 \\
\hline United States & 0.48 & -2.79 & -1.70 & 0.89 & -1.00 & 0.41 & 0.43 & 0.60 & 0.56 & 0.63 & 1.00 \\
\hline
\end{tabular}


TABLE C. 3

Output elasticity with respect to physical capital, 2001-2011

\begin{tabular}{|c|c|c|c|c|c|c|c|c|c|c|c|}
\hline Country & 2001 & 2002 & 2003 & 2004 & 2005 & 2006 & 2007 & 2008 & 2009 & 2010 & 2011 \\
\hline Australia & 0.84 & 0.74 & 0.45 & 1.04 & 0.58 & 0.37 & 0.41 & 0.42 & 0.71 & 0.52 & 0.85 \\
\hline Austria & 0.95 & 0.74 & 0.54 & 0.70 & 0.48 & 0.54 & 0.43 & 0.62 & 0.70 & 0.42 & 0.76 \\
\hline Belgium & 0.75 & 0.72 & 0.52 & 0.44 & 0.39 & 0.33 & 0.79 & 0.86 & 0.50 & 0.61 & 0.64 \\
\hline Brazil & 0.60 & 0.74 & 0.38 & 0.45 & 0.50 & 0.50 & 0.41 & 1.06 & 0.55 & 0.89 & 0.89 \\
\hline Canada & 0.71 & 0.48 & 0.45 & 0.94 & 0.37 & 0.78 & 0.29 & 0.72 & 0.77 & 0.90 & 0.55 \\
\hline Chile & 0.72 & 0.45 & 0.47 & 0.61 & 0.42 & 0.59 & 0.91 & 0.70 & 0.48 & 0.65 & 0.47 \\
\hline China & 0.72 & 0.33 & 0.36 & 0.47 & 0.83 & 0.45 & 0.78 & 0.42 & 0.51 & 0.55 & 0.44 \\
\hline Czech Republic & 0.39 & 0.55 & 0.45 & 0.72 & 0.66 & 0.52 & 0.49 & 0.44 & 0.36 & 0.58 & 0.56 \\
\hline Denmark & 0.82 & 0.52 & 0.36 & 0.79 & 0.48 & 0.52 & 0.51 & 0.59 & 0.53 & 0.62 & 0.88 \\
\hline Estonia & 0.37 & 0.93 & 0.39 & 0.63 & 0.54 & 0.48 & 0.73 & 0.53 & 0.45 & 0.61 & 0.89 \\
\hline Finland & 0.49 & 0.38 & 0.59 & 0.70 & 0.54 & 0.59 & 0.58 & 0.55 & 0.54 & 0.61 & 0.68 \\
\hline France & 0.48 & 0.44 & 0.87 & 0.72 & 0.74 & 0.46 & 0.60 & 0.46 & 0.75 & 0.64 & 0.61 \\
\hline Germany & 0.57 & 0.51 & 0.48 & 0.85 & 0.85 & 0.48 & 0.61 & 0.51 & 0.76 & 0.71 & 0.75 \\
\hline Greece & 0.58 & 0.50 & 0.58 & 1.08 & 0.77 & 0.97 & 0.73 & 0.65 & 0.75 & 0.74 & 0.72 \\
\hline Hungary & 0.93 & 0.66 & 0.35 & 0.49 & 0.35 & 0.92 & 0.34 & 0.61 & 0.46 & 0.36 & 0.41 \\
\hline Iceland & 1.06 & 0.77 & 0.38 & 0.45 & 0.37 & 0.58 & 0.69 & 0.63 & 0.49 & 0.39 & 0.36 \\
\hline India & 0.32 & 0.77 & 0.70 & 0.78 & 0.51 & 0.55 & 0.55 & 0.41 & 0.68 & 0.54 & 0.66 \\
\hline Indonesia & 0.77 & 0.72 & 0.62 & 0.59 & 0.51 & 0.61 & 0.82 & 0.65 & 0.35 & 0.39 & 0.49 \\
\hline Ireland & 0.38 & 0.39 & 0.70 & 0.71 & 0.51 & 0.64 & 0.63 & 0.90 & 0.70 & 0.85 & 0.76 \\
\hline Israel & 0.46 & 0.47 & 0.50 & 0.43 & 0.51 & 0.46 & 0.70 & 0.81 & 0.58 & 0.50 & 0.75 \\
\hline Italy & 0.74 & 0.52 & 0.40 & 0.40 & 0.52 & 0.68 & 0.54 & 0.62 & 0.68 & 0.91 & 0.76 \\
\hline Japan & 0.52 & 0.68 & 0.71 & 0.71 & 0.52 & 0.68 & 0.79 & 0.35 & 0.75 & 0.61 & 0.43 \\
\hline Korea, Rep. & 0.58 & 0.69 & 0.45 & 0.72 & 0.53 & 0.85 & 0.80 & 0.38 & 0.77 & 0.36 & 0.59 \\
\hline Luxembourg & 0.46 & 0.47 & 0.56 & 0.56 & 0.56 & 0.66 & 0.59 & 0.84 & 0.43 & 0.35 & 0.71 \\
\hline Mexico & 0.48 & 0.42 & 0.46 & 0.70 & 0.58 & 0.48 & 0.69 & 0.85 & 0.50 & 0.42 & 0.37 \\
\hline Netherlands & 0.48 & 0.39 & 0.68 & 0.35 & 0.44 & 0.36 & 0.74 & 0.85 & 0.75 & 0.44 & 0.50 \\
\hline New Zealand & 0.78 & 0.51 & 0.66 & 0.43 & 0.47 & 0.48 & 0.71 & 0.51 & 0.43 & 0.44 & 0.40 \\
\hline Norway & 0.72 & 0.54 & 0.57 & 0.63 & 0.55 & 0.98 & 0.76 & 0.51 & 0.29 & 0.31 & 0.63 \\
\hline Poland & 0.74 & 0.59 & 1.07 & 0.65 & 0.57 & 0.79 & 0.35 & 0.69 & 0.58 & 0.40 & 0.90 \\
\hline Portugal & 0.71 & 0.48 & 0.67 & 0.41 & 0.44 & 0.53 & 0.44 & 0.42 & 0.57 & 0.48 & 0.46 \\
\hline Russian Federation & 0.62 & 0.50 & 0.95 & 0.48 & 0.49 & 0.88 & 0.53 & 0.45 & 0.68 & 1.00 & 0.36 \\
\hline Slovak Republic & 0.48 & 0.86 & 0.66 & 0.55 & 0.52 & 0.67 & 0.71 & 0.52 & 0.85 & 0.66 & 0.43 \\
\hline Slovenia & 0.83 & 0.89 & 0.96 & 0.51 & 0.56 & 0.40 & 0.69 & 0.42 & 0.32 & 0.50 & 0.42 \\
\hline South Africa & 0.57 & 0.58 & 0.66 & 0.39 & 0.58 & 0.70 & 0.68 & 0.53 & 0.69 & 0.53 & 0.53 \\
\hline Spain & 0.59 & 0.67 & 0.37 & 0.76 & 0.58 & 0.74 & 0.69 & 0.71 & 0.49 & 0.53 & 0.52 \\
\hline Sweden & 0.58 & 0.66 & 0.41 & 0.76 & 0.52 & 0.62 & 0.50 & 0.50 & 1.04 & 0.38 & 0.51 \\
\hline Switzerland & 0.66 & 0.73 & 0.40 & 0.47 & 0.52 & 0.41 & 0.60 & 0.39 & 0.50 & 0.57 & 0.53 \\
\hline Turkey & 0.62 & 0.31 & 0.61 & 0.53 & 0.52 & 0.48 & 0.96 & 0.56 & 0.55 & 0.48 & 0.54 \\
\hline United Kingdom & 0.75 & 0.64 & 0.75 & 0.67 & 0.70 & 0.37 & 0.65 & 0.55 & 0.54 & 0.50 & 0.55 \\
\hline United States & 0.74 & 0.93 & 1.01 & 0.57 & 0.78 & 0.39 & 0.51 & 0.41 & 0.42 & 0.64 & 0.55 \\
\hline
\end{tabular}


TABLE C.4

Annual average of output elasticities with respect to human $\left(\varepsilon_{h}\right)$ and physical capital $\left(\varepsilon_{k}\right)$ and returns to scale $(\varepsilon)$

\begin{tabular}{|c|c|c|c|}
\hline Country & $\varepsilon_{h}$ & $\varepsilon_{k}$ & $\varepsilon$ \\
\hline Australia & -0.13 & 0.63 & 0.50 \\
\hline Austria & 0.28 & 0.62 & 0.91 \\
\hline Belgium & 0.38 & 0.60 & 0.97 \\
\hline Brazil & 0.35 & 0.63 & 0.98 \\
\hline Canada & -0.20 & 0.63 & 0.43 \\
\hline Chile & -0.13 & 0.59 & 0.45 \\
\hline China & 0.17 & 0.53 & 0.70 \\
\hline Czech Republic & 0.72 & 0.52 & 1.24 \\
\hline Denmark & 0.28 & 0.60 & 0.89 \\
\hline Estonia & 0.21 & 0.59 & 0.81 \\
\hline Finland & 0.52 & 0.57 & 1.09 \\
\hline France & 0.24 & 0.62 & 0.86 \\
\hline Germany & 0.32 & 0.64 & 0.96 \\
\hline Greece & -0.39 & 0.73 & 0.34 \\
\hline Hungary & 0.06 & 0.54 & 0.59 \\
\hline Iceland & 0.17 & 0.56 & 0.73 \\
\hline India & 0.24 & 0.59 & 0.83 \\
\hline Indonesia & 0.61 & 0.59 & 1.20 \\
\hline Ireland & 0.20 & 0.65 & 0.86 \\
\hline Israel & 0.48 & 0.56 & 1.04 \\
\hline Italy & 0.25 & 0.61 & 0.86 \\
\hline Japan & 0.33 & 0.61 & 0.94 \\
\hline Korea, Rep, & 0.22 & 0.61 & 0.83 \\
\hline Luxembourg & 0.58 & 0.56 & 1.14 \\
\hline Mexico & 0.46 & 0.54 & 1.00 \\
\hline Netherlands & 0.21 & 0.54 & 0.76 \\
\hline New Zealand & 0.34 & 0.53 & 0.87 \\
\hline Norway & 0.50 & 0.59 & 1.09 \\
\hline Poland & -0.35 & 0.67 & 0.31 \\
\hline Portugal & 0.20 & 0.51 & 0.71 \\
\hline Russian Federation & -0.41 & 0.63 & 0.22 \\
\hline Slovak Republic & 0.15 & 0.63 & 0.78 \\
\hline Slovenia & -0.07 & 0.59 & 0.52 \\
\hline South Africa & 0.71 & 0.59 & 1.29 \\
\hline Spain & 0.45 & 0.60 & 1.06 \\
\hline Sweden & 0.35 & 0.59 & 0.93 \\
\hline Switzerland & 0.59 & 0.53 & 1.12 \\
\hline Turkey & 0.33 & 0.56 & 0.89 \\
\hline United Kingdom & 0.33 & 0.61 & 0.94 \\
\hline United States & -0.05 & 0.63 & 0.59 \\
\hline
\end{tabular}


TABLE C.5

Sources of economic growth, 2001-2011: compound annual rate

\begin{tabular}{|c|c|c|c|c|c|c|c|c|}
\hline \multirow[b]{2}{*}{ Country } & \multirow[b]{2}{*}{$\begin{array}{l}\text { Economic } \\
\text { growth }^{1}\end{array}$} & \multirow[b]{2}{*}{$\begin{array}{l}\text { Human Capital } \\
\text { accumulation }^{2}\end{array}$} & \multirow[b]{2}{*}{$\begin{array}{l}\text { Physical Capital } \\
\text { accumulation }\end{array}$} & \multicolumn{4}{|c|}{ Productivity Change } & \multirow[b]{2}{*}{$\begin{array}{l}\text { Random } \\
\text { Shocks }\end{array}$} \\
\hline & & & & TFP & $\begin{array}{l}\text { Technical } \\
\text { Change }\end{array}$ & $\begin{array}{l}\text { Technical } \\
\text { Efficiency }\end{array}$ & $\begin{array}{c}\text { Scale } \\
\text { Effects }\end{array}$ & \\
\hline Australia & 0.01 & -0.06 & 2.02 & 1.53 & -7.07 & 9.58 & -0.98 & -3.48 \\
\hline Austria & 0.48 & 0.10 & 2.14 & 0.67 & -7.07 & 7.95 & -0.21 & -2.42 \\
\hline Belgium & -0.04 & 0.10 & 2.84 & -0.50 & -7.07 & 6.65 & -0.09 & -2.48 \\
\hline Brazil & 0.55 & 0.34 & 1.41 & 1.40 & -7.07 & 8.50 & -0.03 & -2.61 \\
\hline Canada & -0.24 & -0.27 & 2.05 & -0.40 & -7.07 & 7.68 & -1.01 & -1.62 \\
\hline Chile & 2.59 & -0.20 & 4.73 & 0.42 & -7.07 & 9.97 & -2.48 & -2.36 \\
\hline China & 7.68 & 0.21 & 9.31 & -3.58 & -7.07 & 6.36 & -2.87 & 1.73 \\
\hline Czech Republic & 1.21 & 0.05 & 1.61 & 0.43 & -7.07 & 7.10 & 0.39 & -0.88 \\
\hline Denmark & 1.10 & 0.06 & 3.42 & 0.75 & -7.07 & 8.21 & -0.40 & -3.12 \\
\hline Estonia & 4.34 & 0.06 & 6.88 & -2.14 & -7.07 & 6.27 & -1.33 & -0.47 \\
\hline Finland & 0.55 & 0.13 & 2.01 & 1.51 & -7.07 & 8.38 & 0.19 & -3.10 \\
\hline France & 0.70 & 0.17 & 4.70 & -1.69 & -7.07 & 6.06 & -0.68 & -2.49 \\
\hline Germany & 1.13 & 0.34 & 2.14 & 0.39 & -7.07 & 7.55 & -0.09 & -1.74 \\
\hline Greece & 0.57 & -1.24 & 9.40 & -6.05 & -7.07 & 6.40 & -5.38 & -1.55 \\
\hline Hungary & 2.00 & 0.02 & 6.49 & -3.41 & -7.07 & 6.29 & -2.64 & -1.10 \\
\hline Iceland & 0.59 & 0.16 & 1.22 & 2.95 & -7.07 & 10.39 & -0.37 & -3.75 \\
\hline India & 6.29 & 0.27 & 5.96 & 4.74 & -7.07 & 12.87 & -1.06 & -4.69 \\
\hline Indonesia & 3.55 & 0.43 & 3.24 & 1.59 & -7.07 & 7.93 & 0.73 & -1.72 \\
\hline Ireland & 2.97 & 0.10 & 8.35 & -3.74 & -7.07 & 4.54 & -1.22 & -1.75 \\
\hline Israel & -1.86 & 0.06 & -1.05 & 0.93 & -7.07 & 8.04 & -0.04 & -1.79 \\
\hline Italy & -0.51 & 0.12 & 2.47 & -0.89 & -7.07 & 6.54 & -0.36 & -2.22 \\
\hline Japan & 0.73 & 0.14 & 1.98 & 1.73 & -7.07 & 8.91 & -0.12 & -3.12 \\
\hline Korea, Rep. & 2.35 & 0.14 & 5.26 & -0.84 & -7.07 & 7.16 & -0.94 & -2.21 \\
\hline Luxembourg & -0.87 & 0.14 & 1.41 & -0.96 & -7.07 & 5.88 & 0.22 & -1.45 \\
\hline Mexico & 1.18 & 0.44 & 2.55 & 1.44 & -7.07 & 8.51 & 0.00 & -3.25 \\
\hline Netherlands & 0.96 & 0.05 & 4.28 & -1.15 & -7.07 & 6.97 & -1.05 & -2.22 \\
\hline New Zealand & -0.18 & 0.12 & 0.43 & 2.80 & -7.07 & 9.94 & -0.07 & -3.53 \\
\hline Norway & 1.78 & 0.23 & 2.63 & -0.43 & -7.07 & 6.38 & 0.25 & -0.65 \\
\hline Poland & 2.77 & -0.27 & 3.65 & 1.00 & -7.07 & 10.39 & -2.32 & -1.61 \\
\hline Portugal & 1.67 & 0.17 & 5.59 & -1.83 & -7.07 & 6.92 & -1.67 & -2.27 \\
\hline Russian Federation & 7.77 & -0.40 & -0.39 & 14.79 & -7.07 & 21.24 & 0.62 & -6.23 \\
\hline Slovak Republic & 3.39 & 0.02 & 3.99 & 0.55 & -7.07 & 8.52 & -0.90 & -1.18 \\
\hline Slovenia & 0.88 & -0.02 & 4.97 & -2.77 & -7.07 & 6.65 & -2.35 & -1.29 \\
\hline South Africa & 2.30 & 0.28 & 1.61 & 2.23 & -7.07 & 8.75 & 0.55 & -1.82 \\
\hline Spain & 1.75 & 0.28 & 5.25 & 0.00 & -7.07 & 6.75 & 0.33 & -3.78 \\
\hline Sweden & 0.89 & 0.08 & 2.14 & -0.14 & -7.07 & 7.07 & -0.14 & -1.18 \\
\hline Switzerland & 1.53 & 0.13 & 1.30 & 1.72 & -7.07 & 8.63 & 0.16 & -1.62 \\
\hline Turkey & 4.57 & 0.40 & 4.72 & 2.64 & -7.07 & 10.25 & -0.54 & -3.19 \\
\hline United Kingdom & 0.46 & 0.14 & 3.84 & -1.67 & -7.07 & 5.66 & -0.25 & -1.86 \\
\hline United States & 1.37 & -0.02 & 2.96 & 0.20 & -7.07 & 8.48 & -1.21 & -1.76 \\
\hline
\end{tabular}

(1) Growth rate of GDP per worker. (2) Growth rates of human and physical capital per worker weighted by input expenditure share.

(3) Obtained as a residual. 